\title{
Does Trade Foster Employment Growth in Emerging Markets? Evidence from Turkey
}

\author{
ALESSIA LO TURCO and DANIELA MAGGIONI*
}

Università Politecnica delle Marche, Ancona, Italy

\begin{abstract}
Summary. - This work investigates the impact of importing, exporting, and two-way trading on firm labor demand in Turkish manufacturing. Adopting Multiple Propensity Score Matching techniques and Difference in Difference estimator, we support the positive internationalization impact on firm employment for an emergent country. Our evidence reveals the existence of complementarity effects between exports and imports, which is strengthened for high trade intensity firms. Furthermore, only high intensity exporting seems to promote the workforce skill upgrading in terms of an increase in the R\&D worker share. The employment creation effect of firm internationalization reflects its large positive impact on firm production scale.

(C) 2013 Elsevier Ltd. All rights reserved.
\end{abstract}

Key words - importer, exporter, two-way trader, employment, firm growth, Turkey

\section{INTRODUCTION}

The recent economic success of emerging countries rests largely on their competitive manufacturing sectors, which are increasingly integrated into the world economy. On the one hand, the export market represents an unprecedented opportunity for growth and innovation for manufacturing firms. On the other hand, imported inputs enhance the possibilities for acquiring advanced technologies and/or exploiting new complementarities in production. Although both importing and exporting activities may occasion an internal restructuring process and bring about efficiency gains (Halpern, Koren, \& Szeidl, 2005; Wagner, 2007, 2012) the impact on firm employment levels is more uncertain. Productivity improvements arising from import and export activities might, for example, foster a permanent shift toward labor-saving technologies, with a consequent reduction in firm employment. Also, imported inputs may directly substitute for domestic labor. Nevertheless, this is only part of the story, and there are other channels that instead suggest the employment-creation effects of trade. If higher productivity fostered by internationalization leads to improved competitiveness and to an expansion of firm output and market share, trade could positively affect firm employment levels, even in the face of a reduction in overall labor intensity in manufacturing. Finally, exporting might directly lead to an expansion of the scale of firm operations and thus of firm employment, as it opens new potential business opportunities and increases the relevant market size of firms. Policy makers in developing economies should, then, be concerned about the international integration of manufacturing firms, as it may have important consequences for longterm trends in employment creation and economic growth. Indeed, countries' integration into the global economy brings about an important restructuring process, with low productivity firms exiting manufacturing (Fernandes, 2007; Melitz, 2003; Pavcnik, 2002; Paus, Reinhardt, \& Robinson, 2003). If redundant workers are then reallocated to low productivity and low growth sectors (e.g., services), the country will experience low productivity growth (Rodrik \& McMillan, 2011). On the other hand, if trade fosters an increase in manufacturing firms' demand for labor, redundant labor could be reallocated within the manufacturing sector to trading firms, which are usually the most productive firms in the economy. As a consequence, a country may experience increased productivity growth.

Our aim, then, is to explore the effect of trade on firm employment and employment composition in an emerging country framework by examining the Turkish manufacturing sector, thus contributing to the developing economy literature that has mainly investigated the relative demand for skilled labor (Fajnzylber \& Fernandes, 2009; Görg \& Strobl, 2002; Harrison \& Hanson, 1999; Pavcnik, 2003). In particular, our study adds to previous empirical work on Turkey (Demir, 2010, 2013; Meschi, Taymaz, \& Vivarelli, 2011; Yasar \& Morrison Paul, 2008) by providing, for the first time, comprehensive evidence regarding the causal effects of importing, exporting, and joint importing and exporting on firm level labor demand, using recent and representative data. The empirical strategy we adopt is based on a combination of Multiple Propensity Score Matching (MPSM) and Difference-in-Differences (DID) estimation. This methodological choice allows us to dissect and isolate the role of each international strategyimporting, exporting, and two-way trading - on employment, by controlling for selection on time invariant unobservables. The focus on developing countries is of particular interest in the study of the trade-employment nexus for several reasons. First, while developed countries' importing activities, especially from low-income countries, are often driven by labor cost saving objectives, firms in emerging markets are more likely to be seeking technology and high-quality inputs when they engage in cross-border trade. This may, directly or

\footnotetext{
* The data used in this work are from the Foreign Trade Data, the Annual Business Statistics and the Production Surveys provided by Turkish Statistical Office (Turkstat). All elaborations have been conducted at the Microdata Research Centre of Turkstat under the respect of the law on the statistic secret and the personal data protection. The results and the opinions expressed in this article are exclusive responsibility of the authors and, by no means, represent official statistics. We are grateful to Bülent Tungul, Mahamut Özgür, Kenan Orhan and Erdal Yildirim from Turkstat for their help with Foreign Trade Data. We also thank Vedat Metin, Ülkü Ünsal and Oğuzhan Turkoğlu from Dissemination Department. We are grateful to Elizabeth J. Casabianca, Fabio Fiorillo, Alberto Russo and Stefano Staffolani for useful comments and suggestions. Final revision accepted: June 7, 2013.
} 
indirectly - indirectly through productivity improvements induced by technology transfers embodied in trade flows (Halpern et al., 2005)_affect firm level employment and employment composition in different ways than in a developed economy framework. Second, exports may offer firms in developing countries - more than firms in developed countries - the opportunity to substantively enlarge their scale of operations, as their domestic markets may be small. Third, global production chains intensively involve firms located in emerging economies, and it is important to understand whether firms entering international production networks can create important employment opportunities within developing economies.

Within this framework, Turkey is an interesting case. Beginning in the 1980s, the country has undergone a continuous and growing process of integration into the global economy. Empirical evidence confirms that productivity gains are associated with the internationalization of Turkish firms (Maggioni, 2012; Morrison \& Yasar, 2007; Yasar \& Rejesus, 2005) and this hints at the possibility of pro-competitive effects of firm activities in foreign markets. However, limited empirical evidence exists on the recent consequences of firm trade on Turkish manufacturing employment, a gap that we attempt here to fill. During the period of our analysis, 2003-08, the Turkish manufacturing sector experienced an increase in the absolute size of its labor force and now accounts for a significant share of total Turkish employment. Nevertheless, its share of total employment decreased from about $41 \%$ in 2003 to $34 \%$ in 2008 and, despite sustained GDP growth (6\% annually, on average, during our sample period), the Turkish unemployment rate has remained very high (about 11\%), while the employment rate has remained modest (well below 50\%). Turning to the country's integration in the global economy, in our sample period, exports and imports grew dramatically $\left(25 \%\right.$ and $19 \%$, respectively $\left.{ }^{1}\right)$, compared to previous decades. In this context, it is crucial to clarify whether firm internationalization strategies have sustained manufacturing labor demand or have contributed to stagnation in the labor market. This point is crucial for anticipating future effects of ongoing integration into the global economy on unemployment reduction and employment creation. Furthermore, our investigation aims to disclose the impact of a firm's trade integration strategies on its employment composition in terms of the ratio of R\&D to non-R\&D workers. Trade may indeed represent a channel of technology and knowledge transfers (Fernandes \& Paunov, 2010; Lo Turco \& Maggioni, 2012a), and firms may engage in innovation and endow themselves with a skilled workforce to take advantage of the opportunities presented by international markets. The latter channel may clearly play an important role in the future growth pattern of the economy and in the development process, increasingly based on knowledge creation and innovation.

The work is organized as follows: the next section reviews the relevant literature; Section 3 presents the data and some firm level descriptive evidence on trade and employment; Section 4 addresses the empirical strategy and the estimation technique; Section 5 displays the main results of our analysis; Section 6 investigates the role of firm trade intensity. Finally, Section 7 discusses the evidence and concludes.

\section{LITERATURE REVIEW}

Our work is close to the large literature on the impact of imports on firm level labor demand in developing countries. ${ }^{2}$ Most of the empirical contributions focus on the impact of trade on the demand for skilled labor, motivated by the theoretical possibility that foreign inputs and exported products may lead to skill upgrading of firm labor. Indeed, trade may favor technology diffusion from the North to the South (Pissarides, 1997). Also, the growth of new intermediate imports and the insourcing of higher skill intensive production stages may drive an increase in skill intensity in the developing country manufacturing sector (Feenstra \& Hanson, 1997). In both cases, a larger share of skilled workers is required to cope with new tasks and new technologies. However, existing evidence on this issue is not conclusive. ${ }^{3}$ While it has been shown that imports did not affect the relative demand for skilled workers in Chilean plants (Pavcnik, 2003), purchases of foreign machinery raised manufacturing firms' relative skilled labor demand in Ghana in the 1990s, while exports had no effect (Görg \& Strobl, 2002). Similarly, Csillag and Koren (2011) find that Hungarian workers exposed to imported machines earned higher wages than other machine operators in the same firm. On the other hand, increased involvement in imports, exports and foreign direct investment is associated with a reduced demand for skilled labor in China, while the opposite is found in Brazil (Fajnzylber \& Fernandes, 2009) and, with respect to imports and exports, in Mexico (Harrison \& Hanson, 1999). Previous studies, then, show that a positive association may exist, in developing and emerging markets, between the relative demand for skilled labor and firm trade, yet to date few studies have investigated the causal impact of trade on overall firm employment. There are only two recent exceptions: Paunov (2011), who shows that firm import strategies promoted employment in Ecuador between 1997 and 2007 (notably in the aftermath of the crisis); and Park, Yang, Shi, and Jiang (2009), who finds a slightly positive effect of firm exports on employment in China between 1995 and 2000. However, the focus of both studies is on a single internationalization strategy, i.e., either exporting or importing.

For the case of Turkey, some firm level studies analyze the relationship between trade and firm labor demand. For example, Yasar and Morrison Paul (2008) find that the adoption of imported machinery is weakly related to the extent of capitalskill complementarity in a sample of about 800 firms in four selected industries (apparel, textiles, motor vehicles and parts, and meat processing) in the 1995-97 period. For the manufacturing sector as a whole, Meschi et al. (2011) find that between 1992 and 2001, both exporters and firms belonging to sectors experiencing increasing inflows of foreign inputs from advanced countries displayed higher skilled labor costs as a share of total labor costs. Turning to the evidence on firm employment levels, in an analysis of the impact of exchange rate volatility on firm growth, based on a sample of about 500 of the largest Turkish firms, Demir $(2010,2013){ }^{4}$ find a negative direct relationship between firm exports and employment growth, although the relationship is shown to be barely significant under sensitivity checks. ${ }^{5}$ Despite this evidence, which points to a positive relationship between intermediate sectoral imports and firm level skill upgrading and to a negative, but barely significant, direct relationship between firm exporting and firm employment growth in very large firms, there is still scope for a comprehensive and more detailed analysis of firm import and export activities on firm employment in Turkey. Indeed, no previous work has dealt with firm level importing and exporting simultaneously and none has identified a causal effect of trade on firm labor demand. As for the contemporaneous analysis of firm level import and export activities, Yasar and Morrison Paul (2008) do not address firm level exports in their analysis, while Demir $(2010,2013)$ do not account for imports. Meschi et al. (2011) test for both export and import 
measures, but the import indicator used in the analysis is at the sector level and their focus is limited to the firm skill ratio. Thus, they test how relative skilled labor demand differs across firms in sectors with heterogeneous imported input exposures, but not the consequences of the firms' decision to import. Turning to the question of causality, only Demir $(2010,2013)$ show some concern about the endogeneity of their export measure and, as an assessment of the impact of exporting is not their main focus, this concern is addressed by testing for the effects of the export share lagged one year. However, this expedient may not prove sufficient to identify the causal effect of exporting on employment growth. Furthermore, the samples used by Yasar and Morrison Paul (2008) and Demir $(2010,2013)$ are rather small and biased toward very large firms. ${ }^{6}$ Although larger firms trade more and may drive most of the overall effect of trade on employment within manufacturing, the exclusion of medium and small sized firms from the analysis may obscure important information on the relationship investigated.

Thus, using more recent and representative data for Turkey, our work is intended to contribute to the existing literature by providing comprehensive evidence regarding the causal effects of importing, exporting, and joint firm involvement in both strategies on firm employment and the composition of labor demand. We aim to achieve this by highlighting the roles of each trade strategy, both individually and combined with other, and the existence of complementary effects stemming from a deeper participation in international markets.

\section{DATA AND DESCRIPTIVE EVIDENCE}

We use the following data sources to build up our sample. ${ }^{7}$

The Structural Business Statistics (SBS) - The Annual Industry and Service Statistics collect information on firm turnover, input costs, employment, investment activity, the primary 4 digit NACE (Rev 1.1) sector of activity, and the region of location over the period 2003-08. These data cover the whole population of firms with more than 20 employees and a representative sample of firms with less than 20 employees. The economic activities that are included in the survey are the ones in the NACE sections from $\mathrm{C}$ to $\mathrm{K}$, and from $\mathrm{M}$ to $\mathrm{O}$.

The Foreign Trade Statistics (FTS) - Foreign trade flows at firm level provided by Turkstat are sourced from customs declarations and are available for the 2002-09 time span. The import and export flows are collected for the universe of the importers and exporters of goods at 12-digit Gümrük Tarife Istatistik Pozisyonu (GTIP) classification: the first 8 digits correspond to Combined Nomenclature $(\mathrm{CN})$ classification, and the last 4 digits are national.

Sample and definition of starters - To proceed in the exploration of the effect of imports and exports on firm labor demand we restrict our analysis to firms in the manufacturing sector with at least 20 employees, ${ }^{8}$ and we merge the SBS and FTS databases by means of the common firm identifying code, thus gathering information on trade for all of the firms included in the SBS. The initial sample is made up of more than 104,000 firm-year observations in the 2003-08 time span, $63 \%$ of which is active in one of the two trading activities. In particular, on average, in our sample period, $49 \%$ of firms are exporters and $51 \%$ of them are importers. ${ }^{9} \mathrm{~A}$ firm is defined as exporter if it sells a part of its manufacturing turnover abroad. The import status definition is, instead, related to the purchases abroad of intermediates, which are identified according to the Broad Economic Category (BEC) classification. ${ }^{10}$

As discussed in Section 1, our focus is on the trade impact on firm labor demand, both in terms of overall employment level and composition. We measure firm labor as the logarithm of the total number of employees, ${ }^{11} L$, and labor composition as the ratio of $R \& D$ to non- $R \& D$ workers within the firm, $R$. Also, we explore the consequences of internationalization on firm output, $Y$, in order to shed some light on the channels that drive the effects on firm labor demand. Table 5 in the Appendix A presents some descriptive statistics of our outcomes for the whole sample and Table 6 dissects the heterogeneity by sector and firm international status. It is straightforward to notice that, in general, two-way traders display the largest number of employees, the largest output value and the largest $R \& D$ to non-R\&D employees ratio, followed by only importers, only exporters and, finally, non-traders. Also, as expected, the great part of the firm population has a $R \& D$ to non-R $\& D$ employment ratio equal to zero, with about $8.14 \%$ of firms hiring R\&D workers that, however, being our sample quite large, build a group of about 8,500 firms. Moreover, the evidence reveals the existence of relevant differences across sectors with the NACE sectors 32 "Manufacture of radio, television and communication equipment and apparatus" and 24 "Manufacture of chemicals, chemical products and man-made fibres" showing the largest share of firms employing workers in R\&D and the NACE sector 20 "Manufacture of wood and wood products" accounting for a R\&D workers ratio of only $2.36 \%$. Nevertheless, the ranking of internationalized groups of firms in terms of superiority in size and R\&D engagement seems to be preserved within almost all sectors. Being aware of the existence of large differences among sectors, we will control for this feature in our empirical analysis.

To gather a preliminary idea about the relationship between firm employment and its activity in foreign markets we regress the level and variation (indicated by $\Delta$ ) of our outcomes on importer and exporter dummies with the inclusion of two digit NACE Rev 1.1 sector and time dummies. We also test for three mutual exclusive international status, exporter only, importer only, and two-way trader. We implement both pooled OLS and fixed effect estimations. The trade "premia" obtained from these regressions are displayed in Table 1. From the top panel, it emerges that importers and exporters present a larger workforce and a higher $R \& D$ to non-R\&D workers ratio than the remaining firms in the sector. When import and export activity indicators are included in the same specification, an employment premium is displayed for both internationalization strategies compared to the pure domestic activity, even if importing presents a higher premium. For the R\&D workers' ratio, instead, both international strategies enjoy similar premia. Furthermore, our analysis suggests the existence of potential complementarities between export and import activities as two-way starters display substantively larger premia for both the outcomes under investigation with respect to the groups of exporters only and importers only. ${ }^{12}$ When controlling for firm fixed effects, we gather a similar evidence on higher employment level of internationalized firms, even if the trade premia are now substantively downsized. On the contrary, the larger use of R\&D by exporters and importers completely disappears when firm fixed effects are included. A similar pattern of significance and relative coefficient size displayed for the variables in levels is detected in the bottom panel for the regressions of labor growth, while only two-way traders - and just in the pooled estimation - display a significant and important change in the R\&D to non-R\&D workers ratio.

This descriptive analysis reveals a superiority of internationalized firms in terms of both employment level and ratio of R\&D to non-R\&D employees. Nevertheless, it is not possible to draw any conclusion about the causal nexus and in order to highlight the consequences of firm trade for its workforce in 
Table 1. Import and export premia

\begin{tabular}{|c|c|c|c|c|c|c|c|c|c|c|c|c|c|c|c|c|}
\hline \multirow[t]{3}{*}{ Outcome } & \multicolumn{8}{|c|}{ Pooled OLS } & \multicolumn{8}{|c|}{ Fixed Effects } \\
\hline & \multicolumn{4}{|l|}{$L_{t}$} & \multicolumn{4}{|l|}{$\underline{R_{t}}$} & \multicolumn{4}{|l|}{$\underline{L_{t}}$} & \multicolumn{4}{|l|}{$R_{t}$} \\
\hline & (1) & $(2)$ & (3) & (4) & $(5)$ & (6) & $(7)$ & (8) & $(9)$ & (10) & (11) & (12) & (13) & (14) & $(15)$ & (16) \\
\hline Importer & $\begin{array}{c}0.810^{* * * *} \\
{[0.011]}\end{array}$ & & $\begin{array}{c}0.663^{* * *} \\
{[0.010]}\end{array}$ & & $\begin{array}{c}0.357^{* * * *} \\
{[0.025]}\end{array}$ & & $\begin{array}{c}0.252^{* * *} \\
{[0.026]}\end{array}$ & & $\begin{array}{c}0.195^{* * *} \\
{[0.007]}\end{array}$ & & $\begin{array}{c}0.177^{* * *} \\
{[0.007]}\end{array}$ & & $\begin{array}{l}-0.051 \\
{[0.034]}\end{array}$ & & $\begin{array}{l}-0.046 \\
{[0.034]}\end{array}$ & \\
\hline Exporter & & $\begin{array}{c}0.623^{* * *} \\
{[0.011]}\end{array}$ & $\begin{array}{c}0.309^{* * *} \\
{[0.010]}\end{array}$ & & & $\begin{array}{c}0.340^{* * *} \\
{[0.025]}\end{array}$ & $\begin{array}{c}0.221^{* * *} \\
{[0.027]}\end{array}$ & & & $\begin{array}{c}0.152^{* * *} \\
{[0.007]}\end{array}$ & $\begin{array}{c}0.130^{* * * *} \\
{[0.006]}\end{array}$ & & & $\begin{array}{l}-0.047 \\
{[0.031]}\end{array}$ & $\begin{array}{l}-0.042 \\
{[0.032]}\end{array}$ & \\
\hline Importer only & & & & $\begin{array}{c}0.525^{* * *} \\
{[0.013]}\end{array}$ & & & & $\begin{array}{c}0.181^{* * *} \\
{[0.034]}\end{array}$ & & & & $\begin{array}{c}0.198^{* * *} \\
{[0.008]}\end{array}$ & & & & $\begin{array}{l}-0.046 \\
{[0.040]}\end{array}$ \\
\hline Exporter only & & & & $\begin{array}{c}0.150^{* * *} \\
{[0.010]}\end{array}$ & & & & $\begin{array}{c}0.141^{* * *} \\
{[0.033]}\end{array}$ & & & & $\begin{array}{c}0.155^{* * *} \\
{[0.009]}\end{array}$ & & & & $\begin{array}{l}-0.042 \\
{[0.043]}\end{array}$ \\
\hline Two-way trader & & & & $\begin{array}{c}0.971^{* * *} \\
{[0.013]}\end{array}$ & & & & $\begin{array}{c}0.472^{* * *} \\
{[0.029]}\end{array}$ & & & & $\begin{array}{c}0.310^{* * *} \\
{[0.009]}\end{array}$ & & & & $\begin{array}{c}-0.088^{* *} \\
{[0.043]}\end{array}$ \\
\hline Observations & 104,578 & 104,578 & 104,578 & 104,578 & 101,758 & 101,758 & 101,758 & 101,758 & 104,578 & 104,578 & 104,578 & 104,578 & 101,758 & 101,758 & 101,758 & 101,758 \\
\hline$\Delta$ Outcome: & $\Delta L_{t}$ & & & & $\Delta R_{t}$ & & & & $\Delta L_{t}$ & & & & $\Delta R_{t}$ & & & \\
\hline Importer & $\begin{array}{c}0.059^{* * *} \\
{[0.003]}\end{array}$ & & $\begin{array}{c}0.050^{* * *} \\
{[0.003]}\end{array}$ & & $\begin{array}{l}0.038^{* *} \\
{[0.019]}\end{array}$ & & $\begin{array}{l}0.043^{*} \\
{[0.024]}\end{array}$ & & $\begin{array}{c}0.064^{* * *} \\
{[0.006]}\end{array}$ & & $\begin{array}{c}0.061^{* * *} \\
{[0.006]}\end{array}$ & & $\begin{array}{c}0.016 \\
{[0.060]}\end{array}$ & & $\begin{array}{c}0.016 \\
{[0.061]}\end{array}$ & \\
\hline Exporter & & $\begin{array}{c}0.042^{* * *} \\
{[0.003]}\end{array}$ & $\begin{array}{c}0.019^{* * *} \\
{[0.003]}\end{array}$ & & & $\begin{array}{c}0.011 \\
{[0.019]}\end{array}$ & $\begin{array}{l}-0.009 \\
{[0.024]}\end{array}$ & & & $\begin{array}{c}0.036^{* * *} \\
{[0.006]}\end{array}$ & $\begin{array}{c}0.030^{* * *} \\
{[0.006]}\end{array}$ & & & $\begin{array}{c}0.001 \\
{[0.056]}\end{array}$ & $\begin{array}{c}0.000 \\
{[0.057]}\end{array}$ & \\
\hline Importer only & & & & $\begin{array}{c}0.0583^{* * *} \\
{[0.005]}\end{array}$ & & & & $\begin{array}{c}0.046 \\
{[0.031]}\end{array}$ & & & & $\begin{array}{c}0.062^{* * *} \\
{[0.008]}\end{array}$ & & & & $\begin{array}{c}0.091 \\
{[0.069]}\end{array}$ \\
\hline Exporter only & & & & $\begin{array}{c}0.0293^{* * *} \\
{[0.005]}\end{array}$ & & & & $\begin{array}{l}-0.005 \\
{[0.036]}\end{array}$ & & & & $\begin{array}{c}0.031^{* * *} \\
{[0.009]}\end{array}$ & & & & $\begin{array}{c}0.088 \\
{[0.075]}\end{array}$ \\
\hline Two-way trader & & & & $\begin{array}{c}0.0693^{* * *} \\
{[0.0037]}\end{array}$ & & & & $\begin{array}{l}0.034^{*} \\
{[0.020]}\end{array}$ & & & & $\begin{array}{c}0.090^{* * *} \\
{[0.009]}\end{array}$ & & & & $\begin{array}{c}0.027 \\
{[0.074]}\end{array}$ \\
\hline Observations & 78,509 & 78,509 & 78,509 & 78,509 & 76,253 & 76,253 & 76,253 & 76,253 & 78,509 & 78,509 & 78,509 & 78,509 & 76,253 & 76,253 & 76,253 & 76,253 \\
\hline
\end{tabular}

Robust standard errors are in brackets and clustered by firm. Dummy indicators for years and two digit NACE Rev 1.1 sectors are included in all estimations but not reported for the sake of brevity. Importer (Exporter) is a dummy taking value 1 if the firm imports (exports) in year $t$. Two-way trader,

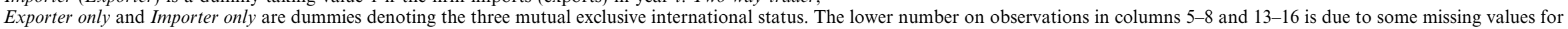
the firm R\&D employment. Both pooled OLS and firm fixed effects estimates are reported.

${ }^{*}$ Significant at $10 \%$ level

${ }^{* *}$ Significant at $5 \%$ level

${ }^{* * *}$ Significant at $1 \%$ level. 
the next section we will follow a MPSM approach. Within this empirical framework, we define export starter as a firm that exports in $t$ and did not export in the previous year, i.e., $t-1$. The same definition is used to obtain the sets of import starters and two-way starters, for which the treatment is the starting of import activity and the concomitant starting of both import and export activity, respectively. These three groups of firms, alternatively, will represent the treated units in our analysis. Being interested in a multitreatment setting, the reference control group may instead consist of both the population of never traders-firms that never export nor import over the sample period-and each group of one-way trade starters when we will test for the entry in both export and import markets as a treatment. We will explain in more detail the empirical framework in the next section. By focusing on starters and never traders we mitigate the potential reverse causality driven by trade persistence over time and we identify the break represented by the entry in the foreign market. ${ }^{13}$ According to this definition, then, we end up with five different waves-year 2004, year 2005, year 2006, year 2007, and year 2008 - of starters and the size of each group is shown in Table 2 by wave and typology of trade activity. It is worth noticing that our final sample for the empirical evaluation of the causal effect of trade on employment will be much smaller than the starting one since it is made up of all those firms that neither export nor import in $t-1$.

\section{THE EMPIRICAL STRATEGY}

In order to assess the impact of trade on employment at the firm level, we follow Lechner $(2001,2002)$ and adopt a multiple treatment approach that allows for a more complex framework where a firm may undergo several treatments at the same time and where importing and exporting may represent both mutually exclusive strategies and joint strategies. If we indicate with $m$ and $x$ respectively the import and export treatments, we have a set of four mutually exclusive states for the firm: $(0,0)$ is the no treatment case, neither importing nor exporting; $(m, 0)$ represents the import starting only; $(0, x)$ represents the export starting only; finally, $(m, x)$ represents the case of both import and export starting.

Our aim is to evaluate the Average Treatment effects on the Treated (ATT) for each treatment $a$. As each participant receives just one treatment, the remaining treatments are potential counterfactuals, and comparison of each state $S$ with the other states leads to a full set of ATT effects calculated as:

$\gamma_{a, b}=E\left(Y_{\text {post }}^{a} \mid S=a\right)-E\left(Y_{\text {post }}^{b} \mid S=a\right)$

with $a, b=(0,0),(m, 0),(0, x),(m, x)$

Table 2. Sample of trade starters

\begin{tabular}{cccc}
\hline & Export & Import & Two-way \\
\hline 2004 & 205 & 273 & 106 \\
2005 & 289 & 344 & 98 \\
2006 & 297 & 418 & 150 \\
2007 & 264 & 351 & 105 \\
2008 & 245 & 214 & 74 \\
Total & 1300 & 1600 & 533 \\
\hline
\end{tabular}

Export, import and two-way label the cohorts of firms that start to export, import and both export and import at time $t$, and did not perform that activity in the previous year. where $\gamma_{a, b}$ denotes the expected (average) effect on outcome $Y$ of treatment $a$, in the post-treatment period, relative to treatment $b$ for a participant drawn randomly from firms undergoing treatment $a$. As $E\left(Y_{\text {post }}^{b} \mid S=a\right)$ is clearly not observable, it is proxied by the outcome of the units that actually undergo the treatment of comparison $b, E\left(Y_{\text {post }}^{b} \mid S=b\right)$. However, participants in different treatments display different characteristics and this proxy may create a selection bias that we try to reduce by applying MPSM and DID estimation techniques. Thanks to the matching approach, we can account for any differences in observables between the treatment and control group, while DID allows for time-invariant unobservables to affect the decision to enter the treatment. As a consequence, our parameters of interest compare the after/before differences in the treated group outcome to the after/before differences in the control group outcome and can be computed as:

$$
\begin{aligned}
\gamma_{a, b}^{D I D}= & {\left[E\left(Y_{\text {post }}^{a} \mid S=a\right)-E\left(Y_{\text {pre }}^{a} \mid S=a\right)\right] } \\
& -\left[E\left(Y_{\text {post }}^{b} \mid S=b\right)-E\left(Y_{\text {pre }}^{b} \mid S=b\right)\right]
\end{aligned}
$$

where $Y$ alternatively represents the firm employment level, the share of $R \& D$ over non-R\&D employees and the output level.

In particular, for each variable of interest, we can obtain different ATT effects for the following pairs:

- $(0, x) /(0,0)$ - Export Starters/Never Traders;

- $(m, 0) /(0,0)$ - Import Starters/Never Traders;

- $(m, x) /(0,0)$ - Two-way Starters/Never Traders;

- $(m, x) /(0, x)$ - Two-way Starters/Export Starters;

- $(m, x) /(m, 0)$ - Two-way Starters/Import Starters;

- $(m, 0) /(0, x)$ - Import Starters/Export Starters;

where the first group of firms represents the group of treated, while the second group of firms builds up the control group. ${ }^{14}$ Due to the informational richness of firm level data and the use of DID, which allows us to take into account the selection on unobservables, we are confident that the conditional independence assumption (Lechner, 2001) holds and, as a consequence, the differences in outcomes between treated units and matched controls can be attributed to the treatment, with resulting effects interpreted as causal. In order to find the control units to be matched with the treated units, we estimate a multinomial logit model for entry into exporting only, importing only and both exporting and importing, from which we recover the propensity scores for each of the four states defined above. The chosen specification includes the first lags of the following firm variables: the logarithms of output $(y)$, labor productivity $(l p)$, employment level $(l)$, and wage $(w)$, a dummy for multiplant firms (multi) and two-digit sector, region and year dummies. The results, displayed in Table 7 in the Appendix A, suggest that firm output positively and significantly affects the adoption of each of the internationalization strategies. The same is true for the status of multiplant firm. In addition, lower wages ease firm entry into export markets and joint firm involvement in export and import markets, but has no effect on initiation of importing activity. It follows that firms in developing countries may take advantage of lower labor costs to compete with foreign firms, and thus cost competition may prove fruitful in fostering firm internationalization. Contrary to previous evidence in the literature, large firms and high productivity firms appear to be less involved in international markets. However the earlier findings are probably driven by the inclusion in the analysis of firm output, which is largely correlated with both firm size and labor productivity. We believe this issue does not pose a problem for our strategy, 
as the purpose of the multinomial logit estimation is not to explain firm selection in foreign markets, but to balance all covariates (Caliendo \& Kopeinig, 2008).

Making use of the resulting propensity scores, we employ Nearest Neighbour (NN) matching with replacement, and we implement the matching cross-section by cross-section. This means that matched controls are from the same year that the respective treatment firm undergoes the treatment and, additionally, that we compare treated firms with control firms in the same treatment and in following years. We then attribute to control firms the same treatment year of the treated units they are matched with, when the latter actually start experiencing the treatment. By investigating the impact of entry into trade, we are not exploring a time-varying treatment. However, in the robustness checks, we take into account the possibility that some firms experiencing the treatment at time $t$ may not be exposed to the treatment in the following years, and thus we will eliminate them from our sample. In Table 8 in the Appendix A, we present some tests of the quality of matching for each of the above pairs. The share of treated firms in the common support is very low for each matching pair. Also, it is evident that when the control group consists of never traders, the matching procedure importantly and significantly helps reduce bias and enables us to obtain matched controls that show no significant observable differences from treated units. This is due to the large sample of never traders. On the contrary, the matching of import starters as the treatment group with export starters as the control group presents some problems highlighted by the increase in the median bias after matching. However, Figure A.0 in the Appendix A shows that the distribution of the propensity scores for matched controls overlaps that for treated firms after the matching procedure has been conducted for all treatments. Summing up, this evidence confirms the general validity of the matching, even if the results obtained from the comparison of the $(\mathrm{m}, 0)$ treatment with the $(0, x)$ counterfactual need to be interpreted with some caution.

\section{RESULTS}

We compute ${ }^{15}$ the DID ATT effects for the year of the treatment and up until two years after the start of the treatment. We then compare outcomes in each of the three years $(t, t+1$, $t+2)$ with those in the pre-treatment year, $t-1 .{ }^{16}$ We report the results for our variables of interest in the first six columns of Table 3. In the last three columns, we examine the role of trade on firms' scales of operation, captured by firm output $(Y)$, which is viewed as the main channel through which importing and exporting may, directly or indirectly, affect employment. Below the coefficients, we show standard errors, computed using three different approaches. First, we calculate analytic standard errors, A.s.e., as suggested in Lechner (2001). Second, to account for possible bias in standard errors driven by the use of estimated propensity scores in the matching, we calculate bootstrapped standard errors (Caliendo \& Kopeinig, 2008), B.s.e. Finally, following Abadie and Imbens (2008), who argue that sub-sampling based bootstrapped standard errors, S.s.e., provide more reliable small sample variance estimates in the case of NN matching,, we report the S.s.e. as well. ${ }^{17}$

We find that internationalization promotes firm employment, contrary to the view that firm importing or exporting gives rise to employment downsizing. In other words, an overall employment reduction resulting from labor saving induced by firm internationalization is not supported by our data. Furthermore, it appears that there are no significant differences between the two types of involvement in foreign markets in terms of their effects on labor demand. Indeed, the ATT effects reveal increased employment for firms starting to import and increased employment of a similar magnitude for non-traders starting to export, while the effect for two-way starters is greater. In the entry year, for example, initiating imports or initiating exports increases firm employment by about $6 \%$ and $7 \%$, respectively, while simultaneously initiating imports and export increases employment by $18 \%$. The employment-enhancing role of internationalization lasts at least until the second year after entry into foreign markets. More importantly, it should be noted that the impact of trade grows over time, even if at a declining rate. For purposes of comparison, in Table 9, we report the unconditional effects, that is, the results of simple OLS regressions on the sample of treated firms and all controls before implementing the propensity score matching and DID estimators. ${ }^{18}$ It is evident that the ATT effects are reduced with respect to unconditional effects, thus revealing the contribution of our adopted empirical strategy. Accounting for observed and unobserved sources of endogeneity in our treatments does indeed allow for a correct identification of the effective causal impact of firm level trade activities on employment. ${ }^{19}$

Our evidence also suggests the existence of complementarity between exports and imports. As discussed above, initiating importing and exporting simultaneously delivers an additional gain that exceeds the sum of the effects associated with the individual trade strategies. Also, the results show that initiation of an additional strategy by firms already involved in foreign markets (either in export or import markets) drives further workforce expansion. These benefits to employment stemming from deeper firm integration into international markets reveal that the adoption of more complex internationalization strategies may activate virtuous circles within firms. This may have important consequences for firm activity, its demand for labor, and ultimately the country labor market.

Turning to the ratio of $\mathrm{R} \& \mathrm{D}$ workers to non-R\&D workers, it emerges that no firm international strategy positively and significantly affects the upgrading of the workforce. This outcome may arise from several factors. First, it may be that the country's specialization sectors are not knowledge and research intensive and that, even in high-tech sectors, the country's production is focused on the lower-end phases of global production chains. It may then be less likely for firms to engage in autonomous R\&D efforts. However, innovation may well run through other channels not properly captured by the measure we are applying to countries at these relatively early stages of development. In this case, indeed, the introduction of new products and processes may simply stem from small incremental innovations that often do not require the establishment of a formal R\&D division. It is worth highlighting that most firms do not employ any R\&D workers at all, as can be gathered from Table 5 in the Appendix A. ${ }^{20}$ This suggests that the ratio of $R \& D$ labor to non-R\&D labor in a firm captures only one dimension of a firm's innovative efforts and calls for caution in inferring general insights into the impact of trade on technological upgrading in Turkish manufacturing. Also, lack of information about the division between blue and white collar labor prevents us from investigating the impact of firm internationalization strategies on the skill ratio and exploring in more depth the process of firm workforce upgrading. The white collars to blue collars ratio, however, has some shortcomings, as clerical workers, usually recorded as skilled workers, often do not contribute to firm innovation activity. In order to extend our investigation of employment composition, we also focused on the impact of trade on the 
Table 3. Employment effects of firm trade: baseline results

\begin{tabular}{|c|c|c|c|c|c|c|c|c|c|}
\hline \multirow[t]{3}{*}{ Outcomes } & \multicolumn{6}{|c|}{ Employment } & \multirow{2}{*}{\multicolumn{3}{|c|}{ Output }} \\
\hline & \multicolumn{3}{|c|}{ Total level } & \multicolumn{3}{|c|}{ R\&D/Non-R\&D } & & & \\
\hline & $\Delta L_{0}$ & $\Delta L_{1}$ & $\Delta L_{2}$ & $\Delta R_{0}$ & $\Delta R_{1}$ & $\Delta R_{2}$ & $\Delta Y_{0}$ & $\Delta Y_{1}$ & $\Delta Y_{2}$ \\
\hline \multicolumn{10}{|c|}{ Export Starters vs Never } \\
\hline$\gamma^{D I D}$ & 0.057 & 0.097 & 0.034 & 0.142 & 0.137 & 0.021 & 0.097 & 0.178 & 0.156 \\
\hline A.s.e. ${ }^{\mathrm{a}}$ & {$[0.021]^{* * *}$} & {$[0.034]^{* * *}$} & {$[0.045]$} & {$[0.146]$} & {$[0.183]$} & {$[0.306]$} & {$[0.027]^{* * *}$} & {$[0.040]^{* * *}$} & {$[0.061]^{* *}$} \\
\hline B.s.e. ${ }^{\mathrm{b}}$ & {$[0.024]^{* *}$} & {$[0.036]^{* * *}$} & {$[0.058]$} & {$[0.159]$} & {$[0.194]$} & {$[0.317]$} & {$[0.030]^{* * *}$} & {$[0.047]^{* * *}$} & {$[0.070]^{* *}$} \\
\hline S.s.e. ${ }^{\mathrm{c}}$ & {$[0.027]^{* *}$} & {$[0.042]$} & {$[0.064]$} & {$[0.169]$} & {$[0.231]$} & {$[0.344]$} & {$[0.033]^{* * *}$} & {$[0.050]^{* * *}$} & {$[0.082]^{*}$} \\
\hline Starters & 1299 & 861 & 493 & 1299 & 861 & 493 & 1299 & 861 & 493 \\
\hline Controls & 1105 & 737 & 424 & 1105 & 737 & 424 & 1105 & 737 & 424 \\
\hline \multicolumn{10}{|c|}{ Import Starters vs Never } \\
\hline$\gamma^{D I D}$ & 0.074 & 0.117 & 0.145 & 0.097 & -0.089 & -0.516 & 0.202 & 0.294 & 0.320 \\
\hline A.s.e. & {$[0.018]^{* * *}$} & {$[0.027]^{* * *}$} & {$[0.038]^{* * *}$} & {$[0.12]$} & {$[0.124]$} & {$[0.197]^{* * *}$} & {$[0.024]^{* * *}$} & {$[0.035]^{* * *}$} & {$[0.050]^{* * *}$} \\
\hline B.s.e. & {$[0.020]^{* * *}$} & {$[0.029]^{* * *}$} & {$[0.040]^{* * *}$} & {$[0.141]$} & {$[0.159]$} & {$[0.224]^{* *}$} & {$[0.028]^{* * *}$} & {$[0.038]^{* * *}$} & {$[0.059]^{* * *}$} \\
\hline S.s.e. & {$[0.025]^{* * *}$} & {$[0.034]^{* * *}$} & {$[0.050]^{* * *}$} & {$[0.148]$} & {$[0.171]$} & {$[0.256]^{* *}$} & {$[0.031]^{* * *}$} & {$[0.045]^{* * *}$} & {$[0.070]^{* * *}$} \\
\hline Starters & 1596 & 1144 & 669 & 1596 & 1144 & 669 & 1596 & 1144 & 669 \\
\hline Controls & 1223 & 882 & 537 & 1223 & 882 & 537 & 1223 & 882 & 537 \\
\hline \multicolumn{10}{|c|}{ Two-way Starters vs Never } \\
\hline$\gamma^{D I D}$ & 0.182 & 0.275 & 0.310 & 0.052 & 0.093 & 0.256 & 0.325 & 0.566 & 0.667 \\
\hline A.s.e. & {$[0.031]^{* * *}$} & {$[0.044]^{* * *}$} & {$[0.060]^{* * *}$} & {$[0.156]$} & {$[0.185]$} & {$[0.236]$} & {$[0.042]^{* * *}$} & {$[0.058]^{* * *}$} & {$[0.080]^{* * *}$} \\
\hline B.s.e. & {$[0.039]^{* * *}$} & {$[0.055]^{* * *}$} & {$[0.077]^{* * *}$} & {$[0.190]$} & {$[0.254]$} & {$[0.351]$} & {$[0.047]^{* * *}$} & {$[0.071]^{* * *}$} & {$[0.100]^{* * *}$} \\
\hline S.s.e. & {$[0.044]^{* * *}$} & {$[0.059]^{* * *}$} & {$[0.080]^{* * *}$} & {$[0.201]$} & {$[0.279]$} & {$[0.373]$} & {$[0.055]^{* * *}$} & {$[0.081]^{* * *}$} & {$[0.104]^{* * *}$} \\
\hline Starters & 533 & 386 & 246 & 533 & 386 & 246 & 533 & 386 & 246 \\
\hline Controls & 492 & 353 & 223 & 492 & 353 & 223 & 492 & 353 & 223 \\
\hline \multicolumn{10}{|c|}{ Two-way Starters vs Export Starters } \\
\hline$\gamma^{D I D}$ & 0.064 & 0.093 & 0.055 & -0.224 & 0.042 & 0.224 & 0.128 & 0.198 & 0.205 \\
\hline A.s.e. & {$[0.031]^{* *}$} & {$[0.043]^{* *}$} & {$[0.066]$} & {$[0.337]$} & {$[0.369]$} & {$[0.615]$} & {$[0.042]^{* * *}$} & {$[0.054]^{* * *}$} & {$[0.083]^{* *}$} \\
\hline B.s.e. & {$[0.035]^{*}$} & {$[0.054]^{*}$} & {$[0.085]$} & {$[0.336]$} & {$[0.382]$} & {$[0.567]$} & {$[0.041]^{* * *}$} & {$[0.066]^{* * *}$} & {$[0.091]^{* *}$} \\
\hline S.s.e. & {$[0.040]$} & {$[0.058]$} & {$[0.081]$} & {$[0.344]$} & {$[0.387]$} & {$[0.568]$} & {$[0.050]^{* *}$} & {$[0.070]^{* * *}$} & {$[0.100]^{* *}$} \\
\hline Starters & 533 & 393 & 271 & 533 & 393 & 271 & 533 & 393 & 271 \\
\hline Controls & 392 & 289 & 201 & 392 & 289 & 201 & 392 & 289 & 201 \\
\hline \multicolumn{10}{|c|}{ Two-way Starters vs Import Starters } \\
\hline$\gamma^{D I D}$ & 0.091 & 0.121 & 0.187 & -0.108 & -0.009 & 0.166 & 0.180 & 0.274 & 0.334 \\
\hline A.s.e. & {$[0.029]^{* * *}$} & {$[0.041]^{* * *}$} & {$[0.059]^{* * *}$} & {$[0.170]$} & {$[0.168]$} & {$[0.219]$} & {$[0.040]^{* * *}$} & {$[0.055]^{* * *}$} & {$[0.079]^{* * *}$} \\
\hline B.s.e. & {$[0.034]^{* * *}$} & {$[0.052]^{* *}$} & {$[0.078]^{* *}$} & {$[0.262]$} & {$[0.286]$} & {$[0.392]$} & {$[0.038]^{* * *}$} & {$[0.064]^{* * *}$} & {$[0.098]^{* * *}$} \\
\hline S.s.e. & {$[0.036]^{* *}$} & {$[0.051]^{* *}$} & {$[0.077]^{* *}$} & {$[0.299]$} & {$[0.337]$} & {$[0.443]$} & {$[0.053]^{* * *}$} & {$[0.076]^{* * *}$} & {$[0.115]^{* * *}$} \\
\hline Starters & 532 & 410 & 281 & 532 & 410 & 281 & 532 & 410 & 281 \\
\hline Controls & 416 & 322 & 225 & 416 & 322 & 225 & 416 & 322 & 225 \\
\hline \multicolumn{10}{|c|}{ Import Starters vs Export Starters } \\
\hline$\gamma^{D I D}$ & -0.001 & -0.051 & 0.022 & 0.111 & -0.381 & 0.301 & -0.077 & -0.087 & -0.079 \\
\hline A.s.e. & {$[0.021]$} & {$[0.034]$} & {$[0.054]$} & {$[0.156]$} & {$[0.235]$} & {$[0.252]$} & {$[0.054]$} & {$[0.073]$} & {$[0.097]$} \\
\hline B.s.e. & {$[0.023]$} & {$[0.035]$} & {$[0.059]$} & {$[0.228]$} & {$[0.338]$} & {$[0.427]$} & {$[0.030]$} & {$[0.045]$} & {$[0.071]$} \\
\hline S.s.e. & {$[0.027]$} & {$[0.040]$} & {$[0.066]$} & {$[0.240]$} & {$[0.375]$} & {$[0.429]$} & {$[0.073]$} & {$[0.091]$} & {$[0.128]$} \\
\hline Starters & 1564 & 1100 & 635 & 1564 & 1100 & 635 & 1564 & 1068 & 612 \\
\hline Controls & 722 & 511 & 321 & 722 & 511 & 321 & 722 & 498 & 310 \\
\hline
\end{tabular}

Standard errors in brackets.

$\Delta L_{0} / \Delta R_{0} / \Delta Y_{0}, \Delta L_{1} / \Delta R_{1} / \Delta Y_{1}$ and $\Delta L_{2} / \Delta R_{2} / \Delta Y_{2}$ refer to the outcome change between $t-1$ and $t, t+1$ and $t+2$, respectively.

The number of treated firms and of their matched controls are reported for each ATT computation.

analytical standard errors computed according to Lechner (2001).

${ }^{\mathrm{b}}$ Bootstrapped standard errors.

${ }^{\mathrm{c}}$ Bootstrapped standard errors from the sub-sampling procedure.

* Significant at $10 \%$ level.

** Significant at 5\% level.

*** Significant at $1 \%$ level.

average firm wage. In the literature, the latter is usually adopted as a proxy for labor quality (Bernard \& Jensen, $2004)$. We found no effect of trade on the average firm wage. ${ }^{21}$

As discussed in Section 1, imports and exports may positively and directly impact a firm's scale of production, thus pushing upward the firm's demand for labor. Also, potential productivity improvements stemming from trade may foster firm competitiveness, which may indirectly lead to growth in firm output and market share ${ }^{22}$. Unfortunately, we cannot compute an indicator of Total Factor Productivity, due to a lack of information about capital assets and to a sample period too short for application of the perpetual inventory method. However, we can investigate whether employment expansion induced by firm internationalization is associated 
with an expansion of output. Building on the MPSM framework described above, we estimate the impact of importing, exporting, and two-way trading on firm output. The relative results are shown in the last three columns of Table 3 . The evidence supports the importance of scale expansion as the dominant channel fueling the increase in employment, as exporting, importing, and two-way trading all positively affect firm output growth. More specifically, the complementarity between the two trade activities is confirmed by the larger ATTs shown for two-way traders.

A comparison of the results on employment and output levels reveals that each internationalization strategy leads to a reduction in firm labor requirements per unit of output and that this effect is stronger when firms begin to import. Nevertheless, based on our evidence, internationalization strategies create a relevant divide across firms in employment capacity. As size plays a key role in various issues crucial to a firmsuch as investments and access to credit-two very different development paths may emerge, one for trading firms and one for strictly domestic firms.

Robustness Checks - We proved the robustness of our baseline findings to a number of checks, as shown in Tables 10-12 in the Appendix A. ${ }^{23}$ In Table 10 we display results for alternative computations of the propensity scores, a different selection of starters and a different definition of importing firms. ${ }^{24}$ We began by trying a different multinomial logit specification in the computation of propensity scores for matching, adding additional observable firm characteristics as regressors. The latter characteristics include the one-year lags of firm status as an investor in tangible and intangible assets, firm status as a subcontractor, and a dummy for firms outsourcing a part of their production to third parties. These variables were excluded in the baseline estimation strategy, as they are usually not available in firm level datasets and we wished to obtain results comparable to those in the standard literature on firm trading activities. However, they can affect both firm internationalization and firm labor demand and thus our previous findings, as a consequence it is important to control for them. Second, we made use of a more restrictive definition of starters, based on firm activity at both $t-1$ and $t-2$. Under this specification, the export/import/two-way starters are those engaged in the relevant activity at time $t$ and not at either time $t-1$ or time $t-2$. Even if the latter definition leads to the computation of treatment effects using a smaller sample, it has the advantage of reducing the incidence of switchers in the treatment sample. Third, we defined import status in terms of overall purchases abroad rather than only purchases of intermediate materials. All these controls deliver results that are substantially similar to those found above. ${ }^{25}$

We further tested the robustness of our findings by adopting two different frameworks in our matching procedure and in the ATT computations and results displayed in Table 11. On the one hand, we matched treated and control firms year-byyear and industry-by-industry in order to account for the influence of time-varying unobserved sectoral heterogeneity in driving firms' participation in international markets and the outcomes of interest. ${ }^{26}$ Matched controls are retrieved from the same year and 2-digit NACE sector as for the treatment firm, and, due to the greater restrictions on matching, we impose a caliper of 0.01 to avoid bad matches. Sectoral heterogeneity does not appear to significantly affect our ATT effects. ${ }^{27}$ On the other hand, to control for the evolution of firm involvement in the international markets of treated firms, we re-computed the ATT effects on the sample of firms continuously exposed to the treatment, thus excluding those firms that switched their international status in the years following their entry into the treatment. As expected, compared to the baseline results for all treated firms, we find higher gains in terms of output and employment in the periods $t+1$ and $t+2$ for internationalized firms continuously involved in foreign markets.

Finally, as we use panel data, we took into account the evolution of time-varying covariates and, after matching, regressed our differenced outcomes in $t+1$ and $t+2$ on the treatment dummy and the lagged values of covariates at times $t$ and $t+1$, respectively. ${ }^{28}$ Table 12 reports the findings for the whole population of treated firms on the left part and for the treated firms continuously exposed to treatment on the right part. Our findings are in general unchanged, even if we infer that starting to import would not have any further positive and significant effect on firm employment for export starters in the years following entry, and the benefits in higher employment of only starting to export are now less robust.

\section{THE ROLE OF TRADE INTENSITY FOR FIRM LABOR DEMAND}

Is employment expansion an effect shared by all firms adopting internationalization strategies or is it confined to those that are more intensively involved in foreign markets? To answer this question, we examine whether the employment effects of trade are homogeneous across high and low trade intensity firms. We split each sample of export, import, and two-way starters into two groups: one for high trade intensity and the other for low trade intensity. The export (import) starters are classified as high intensity starters if their export (import) share is higher than the median share within this firm group. Two-way starters are classified as high intensity firms if their import share and/or export share are higher than the reference median value. ATT effects are then computed, retaining the treated units of each group and their respective control units. As the number of trading groups has doubled and their relative size has consequently shrunk, in this analysis we only focus on never traders as control group. Thus, we estimate whether there is heterogeneity in the impact of initiating trade based on degree of involvement in foreign markets. The picture that emerges in Table 4 is of a positive and significant role of import and export entry, regardless of trade intensity. In comparing high and low intensity export and import initiators, we detect no relevant differences with respect to employment levels. However, the coefficients for low intensity export initiators are barely significant. With respect to two-way starters, we find larger benefits associated with intensive involvement in foreign markets.

Turning to labor composition, some positive benefits for export and import starters are shown for high-intensity traders, even if in some cases the significance level is low. The positive impact for high intensity export starters recalls the general finding on exporting as the main driver of new product introduction (Bratti \& Felice, 2012; Salomon \& Shaver, 2005; Hahn \& Park, 2011), confirmed for Turkey by Lo Turco and Maggioni (2012a). By contrast, the negative coefficient in $t+2$ shown for import starters may be driven by a wider expansion of non-R\&D employment compared to R\&D employment.

Summing up, this investigation reveals positive effects of trade initiation on firm employment, regardless of a firm's degree of involvement in foreign markets. Nevertheless, entry into both import and export markets with high trade intensity may deliver additional gains. In particular, high trade intensity may play a significant role in explaining a firm's internal innovative efforts, as captured by a higher endowment of R\&D 
Table 4. Employment effects: trade intensity

\begin{tabular}{|c|c|c|c|c|c|c|c|c|c|c|c|c|}
\hline & \multicolumn{6}{|c|}{ Employment } & \multicolumn{6}{|c|}{ R\&D/Non-R\&D } \\
\hline & $\Delta L_{0}$ & $\Delta L_{1}$ & $\Delta L_{2}$ & $\Delta L_{0}$ & $\Delta L_{1}$ & $\Delta L_{2}$ & $\Delta R_{0}$ & $\Delta R_{1}$ & $\Delta R_{2}$ & $\Delta R_{0}$ & $\Delta R_{1}$ & $\Delta R_{2}$ \\
\hline & \multicolumn{3}{|c|}{ High intensity } & \multicolumn{3}{|c|}{ Low intensity } & \multicolumn{3}{|c|}{ High Intensity } & \multicolumn{3}{|c|}{ Low intensity } \\
\hline \multicolumn{13}{|c|}{ Export Starter vs Never } \\
\hline$\gamma^{D I D}$ & 0.061 & 0.115 & 0.034 & 0.062 & 0.091 & 0.045 & 0.528 & 0.512 & 0.543 & -0.186 & -0.126 & -0.337 \\
\hline A.s. $e^{a}$ & {$[0.027]^{* *}$} & {$[0.046]^{* *}$} & {$[0.064]$} & {$[0.033]^{*}$} & {$[0.048]^{*}$} & {$[0.064]$} & {$[0.222]^{* *}$} & {$[0.291]^{*}$} & {$[0.513]$} & {$[0.181]$} & {$[0.197]$} & {$[0.317]$} \\
\hline B.s.e $e^{b}$ & {$[0.036]$} & {$[0.055]^{* *}$} & {$[0.091]$} & {$[0.035]^{*}$} & {$[0.050]^{*}$} & {$[0.074]$} & {$[0.260]^{* *}$} & {$[0.318]$} & {$[0.529]$} & {$[0.196]$} & {$[0.280]$} & {$[0.405]$} \\
\hline Starters & 648 & 412 & 228 & 647 & 448 & 264 & 648 & 412 & 228 & 647 & 448 & 264 \\
\hline Controls & 519 & 333 & 187 & 584 & 403 & 236 & 519 & 333 & 187 & 584 & 403 & 236 \\
\hline \multicolumn{13}{|c|}{ Import Starter vs Never } \\
\hline$\gamma^{D I D}$ & 0.052 & 0.122 & 0.185 & 0.086 & 0.106 & 0.104 & 0.277 & -0.003 & -0.414 & -0.062 & -0.167 & -0.67 \\
\hline A.s.e & {$[0.022]^{* *}$} & {$[0.033]^{* * *}$} & {$[0.046]^{* * *}$} & {$[0.029]^{* * *}$} & {$[0.040]^{* * *}$} & {$[0.057]^{*}$} & {$[0.155]^{*}$} & {$[0.140]$} & {$[0.200]^{* *}$} & {$[0.183]$} & {$[0.210]$} & {$[0.360]^{*}$} \\
\hline B.s.e & {$[0.033]$} & {$[0.045]^{* * *}$} & {$[0.058]^{* * *}$} & {$[0.027]^{* * *}$} & {$[0.040]^{* * *}$} & {$[0.056]^{*}$} & {$[0.208]$} & {$[0.208]$} & {$[0.298]$} & {$[0.191]$} & {$[0.224]$} & {$[0.332]^{*}$} \\
\hline Starters & 796 & 559 & 345 & 798 & 583 & 322 & 796 & 559 & 345 & 798 & 583 & 322 \\
\hline Controls & 553 & 390 & 250 & 668 & 490 & 285 & 553 & 390 & 250 & 668 & 490 & 285 \\
\hline \multicolumn{13}{|c|}{ Two-way Starter vs Never } \\
\hline$\gamma^{D I D}$ & 0.218 & 0.320 & 0.369 & 0.086 & 0.153 & 0.160 & -0.035 & -0.122 & 0.053 & 0.282 & 0.637 & 0.675 \\
\hline A.s.e & {$[0.038]^{* * *}$} & {$[0.052]^{* * *}$} & {$[0.071]^{* * *}$} & {$[0.051]^{*}$} & {$[0.077]^{* *}$} & {$[0.104]$} & {$[0.145]$} & {$[0.197]$} & {$[0.246]$} & {$[0.446]$} & {$[0.457]$} & {$[0.602]$} \\
\hline B.s.e & {$[0.047]^{* * *}$} & {$[0.064]^{* * *}$} & {$[0.092]^{* * *}$} & {$[0.078]$} & {$[0.101]$} & {$[0.133]$} & {$[0.240]$} & {$[0.305]$} & {$[0.428]$} & {$[0.342]$} & {$[0.429]$} & {$[0.527]$} \\
\hline Starters & 391 & 288 & 180 & 142 & 98 & 66 & 391 & 288 & 180 & 142 & 98 & 66 \\
\hline Controls & 352 & 257 & 158 & 140 & 96 & 65 & 352 & 257 & 158 & 140 & 96 & 65 \\
\hline
\end{tabular}

Standard errors in brackets.

Analytical standard errors are displayed. $\Delta L_{0} / \Delta R_{0}, \Delta L_{1} / \Delta R_{1}$ and $\Delta L_{2} / \Delta R_{2}$ refer to the outcome change between $t-1$ and $t, t+1$ and $t+2$, respectively.

High intensity Export (Import) starters are the firms with an export (import) share higher than the median share within the starters' group. High intensity Two-way starters are those starters with at least one between import share and export share higher than the reference median value.

${ }^{*}$ Significant at $10 \%$ level.

${ }^{* *}$ Significant at $5 \%$ level.

${ }^{* * *}$ Significant at $1 \%$ level.

workers. Therefore, focusing only on the firm internationalization experience at its starting phase may lead to an underestimation of the importance of firm trade shares. Indeed, firms generally tend to enter foreign markets with low export and import shares and deepen their involvement over time. The availability of a longer panel dataset, then, might reveal further benefits in terms of labor demand stemming from firm trade intensity.

\section{CONCLUSION}

With this paper, we have contributed to the scant literature that exists on the employment consequences of developing country firms' internationalization strategies. Contrary to previous empirical studies, mainly focused on the impact of imports on the ratio of white to blue collar workers, we have analyzed overall firm employment and the composition of the labor force in terms of the ratio of $R \& D$ workers to non-R\&D workers. We have, for the first time, simultaneously investigated firm export and import activities and isolated and compared the impact of each of these trade strategies and of their joint adoption in an MPSM framework. Our results highlight that the penetration of foreign markets and the acquisition of foreign inputs have similar sizable impacts on domestic labor demand. However, simultaneously entering the export and import markets delivers the highest employment effect in the year of entry and in subsequent years, suggesting complementarity between the two strategies. The investigation of trade intensity reveals that the positive effects on labor demand hold, regardless of a firm's degree of involvement in foreign markets. Firms entering both export and import markets with high intensity, however, experience higher employment growth. Finally, only high intensity exporting leads to an increase in the share of R\&D employees, confirming the role of trade as a driver of innovation.

Our results do not support the notion that employment losses result from ongoing international economic integration. On the contrary, within the stagnant Turkish labor market, firm trade activity positively affects manufacturing employment and may counterbalance other factors that negatively affect it. More importantly, we show that entry into foreign markets, whether the import or the export market, leads to significant increases in a firm's scale of operations. It follows that internationalization provides firms with higher growth prospects, representing a fundamental channel for employment creation.

Future research should seek to provide more cross-country evidence regarding the consequences for labor demand of firm involvement in global networks in developing countries. Such countries usually have in common high unemployment rates and thus it is important to understand whether the experience of Turkey is representative of other economies at the same stage of development. Policy makers in emerging economies should therefore seek to enhance firm involvement in foreign markets, as it represents a powerful tool of firm growth. Exploration of other features of the ongoing global integration process, such as the role of domestic and foreign multinational firms, is an additional interesting line of enquiry.

\section{FUNDING}

This work was supported by "Ministero dell'Istruzione, dell'Università e della Ricerca" through the Research Project of National Relevance (PRIN) 2009 on Structural Change. 


\section{NOTES}

1. These figures are sourced from Turkstat Foreign Trade data.

2. Several papers also have addressed with the consequences of trade on the labor demand in advanced economies. The findings usually point at a negative effect of offshoring on the conditional labor demand (Görg \& Hanley, 2005; OECD, 2007) with the major role played by imports of intermediates from cheap labor countries (Cadarso, Gomez, Lopez, \& Tobarra, 2008; Falk \& Wolfmayr, 2008; Harrison \& McMillan, 2007; Lo Turco \& Maggioni, 2012b). The cross-country sector level evidence also shows a negative offshoring impact on the unconditional labor demand (OECD, 2007). The latter detrimental effect is confirmed at plant level on German data, but only when offshoring practices are concomitant to a plant restructuring process consisting in spin-off, closedown, selling-off of parts of the plant (Moser, Urban, \& di Mauro, 2009).

3. While the focus of our work is on the employment more than the wage effects of firm level trade strategies, a large body of the empirical literature has specifically addressed the distributional effects of globalization in developing countries. For an extensive survey see Goldberg and Pavcnik (2007).

4. Although related, the two papers substantially differ. Firstly they focus on two different periods, respectively referring to the period 1983-2005 and 1993-2005. In addition, compared to Demir (2010) which is specifically directed to test the impact of volatility on employment growth and highlights the role of firm exporting and leverage in shaping this relationship, Demir (2013) explores the importance of access to foreign and domestic equity markets in the volatility-employment nexus.

5. The impact of volatility on firm growth is negative especially in high export intensive firms when the 1983-2005 period is considered (Demir, 2013) and positive when the shorter time span is available (Demir, 2010).

6. Demir $(2010,2013)$ indeed rely on a sample drawn from the first and second 500 largest Turkish manufacturing firms and Yasar and Morrison Paul (2008)'s analysis rests on sample where the unskilled workers are on average 116 and skilled workers 36 . This implies a large average firm size.

7. The data used in this work are all from the Turkish National Statistical Office, TurkStat, official sources and are available to any researcher applying for their use. For the respect of confidentiality, though, researchers can only access the data at the microdata centers in Ankara and in some other TurkStat regional offices.

8. Firms with at least 20 employees account for a large share of Turkish manufacturing: they contribute to $87 \%$ of turnover and production value and $75 \%$ of employment in 2009. Similar figures are recorded for previous years. Additionally, since our interest is on trade activity that is mostly performed by large firms, due to the existence of entry sunk costs, we are confident that this sample restriction does not drive to any consistent bias in our results.

9. We dropped some observations with missing or implausible values for our variables of interest and we excluded firms in NACE sectors 16 and 23. Due to the low number of firms in NACE sector 30, we put together firms in sector 30 and sector 31

10. The following BEC codes concern intermediate materials: 111, 121, $21,22,31,322,42$, and 53 .

11. We consider the number of full-time equivalent employees.
12. The R\&D employment is equal to zero for the great part of the sample of firms and this feature may affect the trade premia we found for the R\&D over non-R\&D employees. We have then compared the trade premia on the share of R\&D employees over total firm employment - that is defined on the interval $[0,1]$ - obtained from a OLS estimation with the ones obtained from fractional logit estimations (Papke \& Wooldridge, 2008) which better addresses the existence of a probability mass at zero. We find smaller trade premia for the Importer and Exporter status obtained by exploiting the fractional logit and slightly higher premia for mutual exclusive trade status, however the main messages gathered from the premia analysis do not change. Also, the computation of the ATT effects for the share of R\&D employees over the total employment does not drive to any different conclusion with respect to our baseline results. As a consequence, this set of results is not shown for brevity, but it is available from the authors upon request.

13. In a robustness check we adopt a more stringent definition focusing on export (import) starters identified as the firms exporting (importing) in $t$ and not exporting (importing) in the two previous years, i.e., $t-1$ and $t-2$. The latter definition has the advantage to reduce the incidence of switchers in our treated sample, but presents the disadvantage of reducing the number of observations in the sample.

14. Theoretically, it would be possible to analyze a larger set of treatment combinations, for example, $(0, x) /(m, x)$ where the control group consists of two-way traders. However, this would lead us to select the matched controls in a very small sample and use the same control units several times, as the number of treated is significantly larger than the number of untreated, which would be a poor matching strategy. Thus, we prefer to focus on the cases reported in the text, which we consider to be the most interesting ones for our purpose, as they reflect the beginning or widening of the firm internationalization process. Also, the combination $(0, \mathrm{x}) /(\mathrm{m}, 0)$ represents the specular case of $(\mathrm{m}, 0) /(0, \mathrm{x})$, which is investigated and which we have decided not to present in the text.

15. For the implementation of the DID-PSM procedure we used STATA 10 software and the estimation routine is based on the psmatch2 (Leuven $\&$ Sianesi, 2003) STATA command. All the program files for the MPSM implementation, ATT and standard errors calculation are available from the authors upon request.

16. It is worth noticing that the ATT effects at time $t+1$ and $t+2$ are computed on a smaller sample of firms because of unavailable data for the most recent starter waves, the exit of the treated units and of the respective matched control units.

17. The subsampling procedure has been suggested by Politis, Romano, and Wolf (1999) and recommended by Abadie and Imbens (2008) in the computation of the standard errors of ATT effects obtained from nearestneighbor matching estimators with replacement and a fixed number of neighbors. In this context, Abadie and Imbens (2008) show that bootstrapped standard errors are not valid and may overestimate as well as underestimate the asymptotic standard errors. In the computation of subsampling standard errors we used the $75 \%$ of the sample for each bootstrap draw, following Damijan, Kostevc, and Polanec (2010) and Damijan and Kostevc (2010) who use subsamples consisting of $75-80 \%$ of the population in the original sample.

18. As sector dummies were considered in the matching procedure, we did not include them in the specification for the estimation of the unconditional effects. However, results do not substantially change when sector dummies are added to the basic specification. Results are available upon request. 
19. The only exception is represented by the comparison between Twoway Starters and Import Starters, for which we obtain ATT effects slightly higher than the unconditional ones.

20. Data on the distribution of the $R \& D$ to non-R\&D workers share for the whole sample and by firm international status are available from the authors.

21. For brevity, we do not show these results. However, they are available upon request.

22. Previous studies on preceding time periods have shown a positive impact of exporting on productivity and a positive association between importing and productivity for the Turkish manufacturing firms (Maggioni, 2012; Morrison \& Yasar, 2007; Yasar \& Rejesus, 2005).

23. Besides the checks listed below, we have also applied kernel matching, instead of NN matching, and we get to similar conclusions. The relative results are not shown for the sake of brevity and are available upon request.

24. Since Table 3 has not shown any relevant difference in significance between the two sets of bootstrapped standard errors, B.s.e. and S.s.e., for the robustness checks we only display B.s.e. As a matter of fact, bootstrapping is time consuming and we were forced to leave S.s.e. aside because of time constraints.
25. The only difference concerns the loss of significance for ATT employment effects stemming from the addition of a further internationalization strategy for already exporting or importing firms, when we adopt the more stringent definition of starters. However, it is likely that the latter result is driven by the small size of the starting group of controls in the matching strategy, being the export starters and import starters, respectively.

26. We thank an anonymous referee for suggesting this robustness check.

27. We followed two further strategies to control for the sectoral ad regional heterogeneity. First, after the matching, we regressed-just focusing on the matched sample - our outcomes on the treatment dummy and a set of sector-year and region-year dummies for each treatment pair. Second, we split the sample in two groups of sectors, above and below the median R\&D employment ratio across sectors, and we proceed with the matching and ATT computation separately for each group of firms. In both cases, the results confirm the validity of our analysis and are available from the authors upon request.

28. We also tried to compute the effects in $t+2$ controlling for the lagged values of covariates at both time $t$ and $t+1$ and findings stay substantially unchanged.

\section{REFERENCES}

Abadie, A., \& Imbens, G. W. (2008). On the failure of the bootstrap for matching estimators. Econometrica, 76, 1537-1557.

Bernard, A., \& Jensen, J. (2004). Why some firms export. The Review of Economics and Statistics, 561-569.

Bratti, M., \& Felice, G. (2012). Are Exporters More Likely to Introduce Product Innovations?. The World Economy, 35, 1559-1598.

Cadarso, M. A., Gomez, N., Lopez, L. A., \& Tobarra, M. A. (2008). The eu enlargement and the impact of outsourcing on industrial employment in Spain, 1993-2003. Structural Change and Economic Dynamics, 19, 95-108.

Caliendo, M., \& Kopeinig, S. (2008). Some practical guidance for the implementation of propensity score matching. Journal of Economic Surveys, 22, 31-72.

Csillag, M., \& Koren, M. (2011). Machines and machinists: Capital-skill complementarity from an international trade perspective. CEPR Discussion Papers 8317. CEPR Discussion Papers.

Damijan, J.P., \& Kostevc, C. (2010). Learning from trade through innovation: Causal link between imports, exports and innovation in Spanish microdata. LICOS Discussion Papers 26410. LICOS - Centre for Institutions and Economic Performance, KU Leuven.

Damijan, J. P., Kostevc, C., \& Polanec, S. (2010). From innovation to exporting or vice versa?. The World Economy, 33, 374-398.

Demir, F. (2010). Exchange rate volatility and employment growth in developing countries: Evidence from Turkey. World Development, 38, $1127-1140$.

Demir, F. (2013). Growth under exchange rate volatility: Does access to foreign or domestic equity markets matter?. Journal of Development Economics, 100, 74-88.

Fajnzylber, P., \& Fernandes, A. (2009). International economic activities and skilled labour demand: Evidence from Brazil and China. Applied Economics, 41, 563-577.

Falk, M., \& Wolfmayr, Y. (2008). Services and materials outsourcing to low-wage countries and employment: Empirical evidence from EU countries. Structural Change and Economic Dynamics, 19, 38-52.

Feenstra, R. C., \& Hanson, G. H. (1997). Foreign direct investment and relative wages: Evidence from Mexico's maquiladoras. Journal of International Economics, 42, 371-393.

Fernandes, A. M. (2007). Trade policy, trade volumes and plant-level productivity in Colombian manufacturing industries. Journal of International Economics, 71, 52-71.
Fernandes, A.M., \& Paunov, C. (2010). Does trade stimulate innovation? Evidence from firm-product data. OECD Development Centre Working Papers 286. OECD Publishing.

Goldberg, P. K., \& Pavcnik, N. (2007). Distributional effects of globalization in developing countries. Journal of Economic Literature, 45, $39-82$.

Görg, H., \& Hanley, A. (2005). Labour demand effects of international outsourcing: Evidence from plant-level data. International Review of Economics and Finance, 14, 365-376.

Görg, H., \& Strobl, E. (2002). Relative wages, openness and skill-biased technological change. IZA Discussion Papers 596. IZA.

Hahn, C. H., \& Park, C. G. (2011). Direction of causality in innovationexporting linkage: Evidence from microdata on korean manufacturing. Korea and The World Economy, 12, 367-398.

Halpern, L., Koren, M., \& Szeidl, A. (2005). Imports and productivity. CEPR Discussion Papers 5139. CEPR Discussion Papers.

Harrison, A., \& Hanson, G. (1999). Who gains from trade reform? Some remaining puzzles. Journal of Development Economics, 125-154.

Harrison, A., \& McMillan, M. (2007). Offshoring jobs? Multinationals and US manufacturing employment. IPC Working Paper Series

Lechner, M. (2001). Identification and estimation of causal effects of multiple treatments under the conditional independence assumption. In M. Lechner, \& F. Pfeiffer (Eds.), Econometric evaluation of labour market policies (pp. 1-18). Heidelberg: Physica-Verlag.

Lechner, M. (2002). Some practical issues in the evaluation of heterogeneous labour market programmes by matching methods. Journal of the Royal Statistical Society Series A, 165, 59-82.

Leuven, E., \& Sianesi, B. (2003). Psmatch2: Stata module to perform full Mahalanobis and propensity score matching, common support graphing, and covariate imbalance testing. Statistical Software Components, Boston College Department of Economics

Lo Turco, A., \& Maggioni, D. (2012a). Imports, exports and the firm product scope: Evidence from Turkey. Working Papers 384. Universita' Politecnica delle Marche (I), Dipartimento di Scienze Economiche e Sociali.

Lo Turco, A., \& Maggioni, D. (2012b). Offshoring to high and low income countries and the labor demand. Evidence from Italian firms. Review of International Economics, 20, 636-653.

Maggioni, D. (2012). Learning by exporting in Turkey: An investigation for existence and channels. Global Economy Journal, 12, 5. 
Melitz, M. J. (2003). The impact of trade on intra-industry reallocations and aggregate industry productivity. Econometrica, 71, 1695-1725.

Meschi, E., Taymaz, E., \& Vivarelli, M. (2011). Trade, technology and skills: Evidence from Turkish microdata. Labour Economics.

Morrison, C. J., \& Yasar, M. (2007). International linkages and productivity at the plant level: Foreign direct investment, exports, imports and licensing. Journal of International Economics, 71, 373-388.

Moser, C., Urban, D., \& di Mauro, B.W. (2009). Offshoring, firm performance and establishment-level employment: Identifying productivity and downsizing effects. CEPR Discussion Papers Series 7455. CEPR.

OECD. (2007). Offshoring and employment: Trends and impacts. Technical Report. OECD.

Papke, L. E., \& Wooldridge, J. M. (2008). Panel data methods for fractional response variables with an application to test pass rates. Journal of Econometrics, 145, 121-133.

Park, A., Yang, D., Shi, X., \& Jiang, Y. (2009). Exporting and firm performance: Chinese exporters and the Asian financial crisis. NBER Working Papers 14632. National Bureau of Economic Research, Inc.

Paunov, C. (2011). Imports, innovation and employment after crisis: Evidence from a developing country. OECD Science, Technology and Industry Working Papers 2011/5. OECD Publishing.

Paus, E., Reinhardt, N., \& Robinson, M. (2003). Trade liberalization and productivity growth in Latin American manufacturing, 1970-98. Journal of Policy Reform, 6, 1-15.

Pavcnik, N. (2002). Trade liberalization, exit, and productivity improvement: Evidence from Chilean plants. Review of Economic Studies, 69, 245-276.

Pavcnik, N. (2003). What explains skill upgrading in less developed countries?. Journal of Development Economics, 71, 311-328.
Pissarides, C. A. (1997). Learning by trading and the returns to human capital in developing countries. The World Bank Economic Review, 11, $17-32$.

Politis, N., Romano, J., \& Wolf, M. (1999). Subsampling. New York: Springer Verlag.

Rodrik, D., \& McMillan, R. (2011). Globalization, structural change and productivity growth. NBER Working Paper 17143. NBER.

Salomon, R. M., \& Shaver, M. J. (2005). Learning by exporting: New insights from examining firm innovation. Journal of Economics \& Management Strategy, 14, 431-460.

Wagner, J. (2007). Exports and productivity: A survey of the evidence from firm-level data. The World Economy, 30, 60-82.

Wagner, J. (2012). International trade and firm performance: A survey of empirical studies since 2006. Review of World Economics (Weltwirtschaftliches Archiv), 148, 235-267.

Yasar, M., \& Morrison Paul, C. J. (2008). Capital-skill complementarity, productivity and wages: Evidence from plant-level data for a developing country. Labour Economics, 15, 1-17.

Yasar, M., \& Rejesus, R. M. (2005). Exporting status and firm performance: Evidence from a matched sample. Economics Letters, $88,397-402$.

\section{APPENDIX A. ADDITIONAL TABLES AND FIGURES}

Tables 5-12

A. 0

Table 5. Descriptive statistics of outcomes

\begin{tabular}{|c|c|c|c|c|c|c|c|c|c|c|c|}
\hline \multirow[t]{2}{*}{ 2-Digit Nace } & \multirow[t]{2}{*}{ \# firms } & \multicolumn{2}{|l|}{$L$} & \multicolumn{2}{|l|}{$R$} & \multirow[t]{2}{*}{$\% \mathrm{R}>0$} & \multicolumn{2}{|l|}{$Y$} & \multirow[t]{2}{*}{ Two-way trader } & \multirow[t]{2}{*}{ Exporter only } & \multirow[t]{2}{*}{ Importer only } \\
\hline & & Mean & $\mathrm{Sd}$ & Mean & $\mathrm{Sd}$ & & Mean & $\mathrm{Sd}$ & & & \\
\hline 15 & 10,148 & 3.866 & 0.998 & 0.349 & 2.756 & 6.78 & 15.403 & 1.582 & 25.54 & 9.25 & 14.45 \\
\hline 18 & 17,519 & 3.850 & 0.977 & 0.201 & 1.964 & 4.39 & 14.715 & 1.331 & 30.13 & 11.27 & 13.79 \\
\hline 19 & 2,679 & 3.619 & 0.767 & 0.423 & 2.903 & 5.43 & 14.557 & 1.214 & 37.22 & 14.52 & 17.43 \\
\hline 20 & 1,551 & 3.710 & 0.794 & 0.305 & 3.677 & 2.36 & 14.713 & 1.324 & 35.33 & 9.03 & 15.28 \\
\hline 24 & 3,152 & 4.006 & 1.078 & 2.142 & 5.734 & 27.00 & 15.920 & 1.660 & 62.79 & 5.36 & 17.04 \\
\hline 25 & 5,912 & 3.797 & 0.832 & 0.502 & 2.872 & 8.47 & 15.066 & 1.303 & 47.87 & 13.14 & 11.94 \\
\hline 26 & 6,805 & 3.971 & 0.984 & 0.322 & 1.765 & 7.71 & 14.734 & 1.583 & 25.17 & 13.37 & 10.43 \\
\hline 27 & 3,339 & 4.019 & 1.075 & 0.352 & 2.584 & 6.36 & 15.589 & 1.801 & 48.55 & 9.76 & 10.39 \\
\hline 28 & 7,973 & 3.764 & 0.842 & 0.331 & 2.431 & 5.42 & 14.647 & 1.321 & 32.97 & 14.75 & 10.76 \\
\hline 29 & 8,657 & 3.748 & 0.863 & 1.153 & 4.679 & 14.49 & 14.813 & 1.277 & 49.24 & 14.51 & 11.16 \\
\hline 36 & 5,792 & 3.741 & 0.880 & 0.487 & 2.387 & 9.33 & 14.490 & 1.313 & 35.08 & 23.88 & 7.53 \\
\hline Total & 104,578 & 3.872 & 0.965 & 0.525 & 3.127 & 8.14 & 14.955 & 1.472 & 37.51 & 11.59 & 13.86 \\
\hline
\end{tabular}

Averages for the sample period: 2003-08.

$L, R$, and $Y$ stand respectively for the logarithm of the firm number of full-time equivalent employees, the ratio of R\&D to non-R\&D workers and the logarithm of firm real output (in Turkish Lira).

Two-way trader, Exporter only and Importer only denote to three mutual exclusive firm international status. 
Table 6. Heterogeneity by sector and firm international status

\begin{tabular}{|c|c|c|c|c|c|c|c|c|c|c|c|c|}
\hline \multirow{2}{*}{$\begin{array}{l}\text { 2-Digit } \\
\text { NACE }\end{array}$} & \multicolumn{4}{|l|}{$L$} & \multicolumn{4}{|l|}{$R$} & \multicolumn{4}{|l|}{$Y$} \\
\hline & $\begin{array}{l}\text { Two-way } \\
\text { Traders }\end{array}$ & $\begin{array}{l}\text { Exporters } \\
\text { only }\end{array}$ & $\begin{array}{l}\text { Importers } \\
\text { only }\end{array}$ & Non-Traders & $\begin{array}{l}\text { Two-way } \\
\text { Traders }\end{array}$ & $\begin{array}{l}\text { Exporters } \\
\text { only }\end{array}$ & $\begin{array}{l}\text { Importers } \\
\text { only }\end{array}$ & Non-Traders & $\begin{array}{l}\text { Two-way } \\
\text { Traders }\end{array}$ & $\begin{array}{l}\text { Exporters } \\
\text { only }\end{array}$ & $\begin{array}{l}\text { Importers } \\
\text { only }\end{array}$ & Non-Traders \\
\hline \multirow[t]{2}{*}{15} & 4.708 & 3.728 & 3.997 & 3.431 & 0.650 & 0.343 & 0.221 & 0.236 & 16.741 & 15.169 & 16.075 & 14.586 \\
\hline & $(1.175)$ & $(0.733)$ & $(0.863)$ & $(0.635)$ & (3.567) & $(3.030)$ & $(1.469)$ & (2.492) & $(1.465)$ & $(1.095)$ & $(1.201)$ & $(1.230)$ \\
\hline \multirow[t]{2}{*}{17} & 4.569 & 3.503 & 4.086 & 3.425 & 0.317 & 0.182 & 0.148 & 0.181 & 15.918 & 14.354 & 15.248 & 14.065 \\
\hline & (1.107) & $(0.693)$ & $(0.874)$ & $(0.752)$ & $(2.133)$ & $(1.426)$ & $(1.312)$ & $(1.706)$ & $(1.276)$ & $(0.998)$ & (1.099) & $(1.126)$ \\
\hline \multirow[t]{2}{*}{18} & 4.369 & 3.521 & 4.127 & 3.499 & 0.263 & 0.212 & 0.268 & 0.135 & 15.637 & 14.294 & 15.448 & 13.957 \\
\hline & $(1.071)$ & $(0.716)$ & $(0.890)$ & $(0.794)$ & $(2.124)$ & $(1.754)$ & $(2.517)$ & $(1.682)$ & (1.207) & $(0.957)$ & (1.064) & (1.017) \\
\hline \multirow[t]{2}{*}{19} & 3.973 & 3.425 & 3.608 & 3.290 & 0.595 & 0.465 & 0.323 & 0.245 & 15.286 & 14.108 & 14.855 & 13.694 \\
\hline & $(0.841)$ & $(0.500)$ & $(0.669)$ & $(0.641)$ & (3.269) & $(2.829)$ & $(2.079)$ & $(2.862)$ & $(1.115)$ & $(0.790)$ & $(0.951)$ & $(0.977)$ \\
\hline \multirow[t]{2}{*}{20} & 4.237 & 3.515 & 3.674 & 3.305 & 0.559 & 0.039 & 0.090 & 0.220 & 15.578 & 14.412 & 14.742 & 14.010 \\
\hline & $(0.840)$ & $(0.426)$ & $(0.603)$ & $(0.592)$ & (4.185) & $(0.462)$ & (1.079) & (4.190) & (1.444) & $(0.822)$ & $(0.984)$ & $(0.910)$ \\
\hline \multirow[t]{2}{*}{21} & 4.280 & 3.450 & 3.743 & 3.337 & 0.259 & 0.213 & 0.036 & 0.439 & 16.120 & 14.807 & 15.220 & 14.367 \\
\hline & $(0.915)$ & $(0.504)$ & $(0.742)$ & $(0.653)$ & (1.632) & $(1.422)$ & $(0.494)$ & $(2.926)$ & $(1.286)$ & $(0.745)$ & (1.101) & $(0.998)$ \\
\hline \multirow[t]{2}{*}{22} & 4.093 & 3.615 & 3.641 & 3.425 & 0.581 & 0.459 & 0.694 & 0.227 & 15.526 & 14.719 & 14.888 & 14.227 \\
\hline & $(0.875)$ & $(0.622)$ & $(0.747)$ & $(0.745)$ & (3.689) & (3.274) & $(4.691)$ & (2.092) & (1.197) & (1.029) & (1.134) & (1.152) \\
\hline \multirow[t]{2}{*}{24} & 4.298 & 3.232 & 3.742 & 3.353 & 2.726 & 1.417 & 1.379 & 0.773 & 16.509 & 14.525 & 15.441 & 14.455 \\
\hline & (1.098) & $(0.486)$ & $(0.855)$ & $(0.850)$ & $(6.421)$ & (4.988) & $(4.360)$ & (3.436) & $(1.530)$ & $(0.796)$ & $(1.268)$ & $(1.429)$ \\
\hline \multirow[t]{2}{*}{25} & 4.177 & 3.462 & 3.731 & 3.317 & 0.685 & 0.264 & 0.513 & 0.288 & 15.803 & 14.442 & 15.063 & 14.075 \\
\hline & $(0.852)$ & $(0.496)$ & $(0.751)$ & $(0.607)$ & (3.094) & $(2.091)$ & (3.484) & $(2.442)$ & (1.197) & $(0.748)$ & (0.998) & $(0.952)$ \\
\hline \multirow[t]{2}{*}{26} & 4.743 & 3.694 & 4.283 & 3.598 & 0.631 & 0.231 & 0.535 & 0.151 & 16.058 & 14.128 & 15.551 & 14.074 \\
\hline & (1.085) & $(0.691)$ & $(0.995)$ & $(0.717)$ & (1.983) & (1.963) & (2.495) & $(1.346)$ & $(1.502)$ & $(1.086)$ & $(1.364)$ & $(1.254)$ \\
\hline \multirow[t]{2}{*}{27} & 4.521 & 3.533 & 3.921 & 3.424 & 0.452 & 0.275 & 0.348 & 0.221 & 16.537 & 14.645 & 15.582 & 14.404 \\
\hline & (1.164) & $(0.519)$ & $(0.875)$ & $(0.658)$ & $(2.542)$ & $(2.289)$ & (2.038) & $(2.882)$ & $(1.752)$ & $(0.847)$ & (1.399) & $(1.288)$ \\
\hline \multirow[t]{2}{*}{28} & 4.245 & 3.634 & 3.830 & 3.411 & 0.562 & 0.374 & 0.345 & 0.128 & 15.594 & 14.436 & 14.966 & 13.883 \\
\hline & $(0.862)$ & $(0.617)$ & $(0.818)$ & $(0.702)$ & $(2.841)$ & (3.757) & $(2.112)$ & (1.245) & (1.194) & $(0.881)$ & (1.104) & $(1.070)$ \\
\hline \multirow[t]{2}{*}{29} & 4.072 & 3.437 & 3.668 & 3.329 & 1.533 & 0.837 & 1.540 & 0.418 & 15.426 & 14.326 & 14.751 & 13.918 \\
\hline & $(0.934)$ & $(0.543)$ & $(0.708)$ & $(0.649)$ & (4.884) & (4.855) & (6.385) & $(2.780)$ & $(1.236)$ & $(0.810)$ & $(1.046)$ & $(0.979)$ \\
\hline \multirow[t]{2}{*}{31} & 4.313 & 3.466 & 3.728 & 3.464 & 1.991 & 1.726 & 1.833 & 0.547 & 15.808 & 14.521 & 14.885 & 14.176 \\
\hline & (1.009) & $(0.474)$ & $(0.727)$ & $(0.688)$ & $(5.619)$ & (7.795) & (6.858) & $(2.911)$ & $(1.401)$ & $(0.805)$ & (1.198) & $(1.032)$ \\
\hline \multirow[t]{2}{*}{32} & 4.477 & 3.358 & 3.815 & 3.460 & 6.196 & 0.456 & 1.010 & 0.687 & 16.060 & 14.661 & 14.891 & 14.186 \\
\hline & $(1.412)$ & $(0.489)$ & $(0.920)$ & (1.017) & (13.947) & (1.264) & $(3.122)$ & $(1.876)$ & $(1.869)$ & $(0.862)$ & (1.141) & (1.627) \\
\hline \multirow[t]{2}{*}{33} & 4.017 & 3.534 & 3.601 & 3.317 & 3.049 & 0.000 & 2.081 & 0.848 & 15.447 & 14.105 & 14.641 & 13.562 \\
\hline & $(0.812)$ & $(0.766)$ & $(0.707)$ & $(0.681)$ & $(8.416)$ & $(0.000)$ & $(8.574)$ & $(4.140)$ & $(1.172)$ & $(0.855)$ & (1.075) & (1.247) \\
\hline \multirow[t]{2}{*}{34} & 4.580 & 3.519 & 3.841 & 3.410 & 1.085 & 0.525 & 0.827 & 0.315 & 16.114 & 14.525 & 15.007 & 14.190 \\
\hline & (1.166) & $(0.483)$ & $(0.693)$ & $(0.617)$ & (3.522) & (3.062) & (3.010) & (2.017) & (1.631) & $(0.812)$ & $(0.890)$ & $(1.036)$ \\
\hline \multirow[t]{2}{*}{35} & 4.274 & 3.757 & 4.088 & 3.674 & 0.933 & 0.001 & 0.208 & 0.018 & 16.018 & 14.544 & 15.438 & 13.785 \\
\hline & (1.168) & $(0.705)$ & (1.117) & $(0.826)$ & (4.037) & $(0.013)$ & (1.104) & $(0.511)$ & (1.737) & (1.179) & $(1.562)$ & $(1.234)$ \\
\hline 36 & 4.222 & 3.595 & 3.848 & 3.317 & 0.626 & 0.617 & 0.404 & 0.266 & 15.396 & 14.235 & 14.658 & 13.683 \\
\hline & $(0.977)$ & $(0.664)$ & $(0.736)$ & $(0.659)$ & $(2.512)$ & $(2.944)$ & $(2.119)$ & $(1.770)$ & $(1.290)$ & $(0.883)$ & $(1.140)$ & $(0.997)$ \\
\hline Total & 4.366 & 3.549 & 3.947 & 3.444 & 0.872 & 0.432 & 0.481 & 0.216 & 15.866 & 14.419 & 15.265 & 14.076 \\
\hline
\end{tabular}

Averages for the sample period: $2003 / 2008$. Two-way trader, Exporter only and Importer only denote

In round brackets standard deviations of variables are reported in italic. 
Table 7. MPSM-multinomial logit estimates

\begin{tabular}{lccc}
\hline & $(0, \mathrm{x})$ & $(\mathrm{m}, 0)$ & $(\mathrm{m}, \mathrm{x})$ \\
\hline$y_{t-1}$ & $0.670^{* * *}$ & $1.034^{* * *}$ & $0.960^{* * *}$ \\
& {$[0.042]$} & {$[0.038]$} & {$[0.062]$} \\
$l_{t-1}$ & $-0.475^{* * *}$ & $-0.399^{* * *}$ & $-0.319^{* * *}$ \\
& {$[0.062]$} & {$[0.054]$} & {$[0.085]$} \\
$l_{t-1}$ & $-0.361^{* * *}$ & $-0.272^{* * *}$ & $-0.273^{* * *}$ \\
& {$[0.037]$} & {$[0.035]$} & {$[0.055]$} \\
$w_{t-1}$ & $-0.311^{* * *}$ & -0.001 & $-0.247^{*}$ \\
& {$[0.085]$} & {$[0.083]$} & {$[0.131]$} \\
multi $i_{t-1}$ & $0.295^{* * *}$ & $0.143^{* *}$ & $0.345^{* * *}$ \\
& {$[0.073]$} & {$[0.069]$} & {$[0.109]$} \\
Const. & $-4.991^{* * *}$ & $-12.760^{* * *}$ & $-11.699^{* * *}$ \\
& {$[0.770]$} & {$[0.716]$} & {$[1.156]$} \\
Observations & 17,495 & 17,495 & 17,495 \\
Pseudo- $R^{2}$ & 0.109 & 0.109 & 0.109 \\
Wald Chi ${ }^{2}$ & 2649.213 & 2649.213 & 2649.213 \\
Log-likelihood & -10814.3 & -10814.3 & -10814.3 \\
\hline
\end{tabular}

Standard errors in brackets. Sector and time dummies are included, but not shown.

${ }^{*}$ Significant at $10 \%$ level.

${ }^{* *}$ Significant at $5 \%$ level.

${ }^{* * *}$ Significant at $1 \%$ level.
Table 8. Balancing Tests for MPSM

\begin{tabular}{lcccccc}
\hline & $\begin{array}{c}\text { Treated } \\
\text { firms }\end{array}$ & $\begin{array}{c}\text { Control } \\
\text { firms }\end{array}$ & $\begin{array}{c}\text { \%Treated } \\
\text { firms out of } \\
\text { support }\end{array}$ & & Median bias & $\begin{array}{c}\text { \%Drop } \\
\text { bias }\end{array}$ \\
\cline { 5 - 6 } & & & & & & \\
& & & & & & \\
& & & & & & \\
$(0, x) /(0,0)$ & 1300 & 1105 & 0.08 & 6.97 & 2.15 & 69.20 \\
$(m, 0) /(0,0)$ & 1600 & 1223 & 0.25 & 7.52 & 1.03 & 86.37 \\
$(m, x) /(0,0)$ & 533 & 492 & 0.00 & 10.40 & 1.85 & 82.22 \\
$(m, x) /(0, x)$ & 533 & 392 & 0.00 & 5.55 & 3.30 & 40.57 \\
$(m, x) /(m, 0)$ & 533 & 416 & 0.19 & 5.34 & 2.92 & 45.34 \\
$(m, 0) /(0, x)$ & 1600 & 722 & 2.25 & 4.79 & 5.84 & -22.02 \\
\hline
\end{tabular}

The covariate balancing tests for all the investigated pairs of combinations in the MPSM are shown.

Table 9. Unconditional effects

\begin{tabular}{|c|c|c|c|c|c|c|c|c|c|}
\hline & \multicolumn{6}{|c|}{ Employment } & \multicolumn{3}{|l|}{ Output } \\
\hline & \multicolumn{3}{|l|}{ Total } & \multicolumn{3}{|c|}{ R\&D/Non-R\&D Employment } & \multirow[b]{2}{*}{$Y_{0}$} & \multirow[b]{2}{*}{$Y_{1}$} & \multirow[b]{2}{*}{$Y_{2}$} \\
\hline & $L_{0}$ & $L_{1}$ & $L_{2}$ & $R_{0}$ & $R_{1}$ & $R_{2}$ & & & \\
\hline \multicolumn{10}{|c|}{ Export Starters vs Never } \\
\hline$\gamma^{O L S}$ & $0.080^{* * *}$ & $0.106^{* * *}$ & $0.102^{* * *}$ & $0.138^{*}$ & $0.191^{* * *}$ & 0.141 & $0.412^{* * *}$ & $0.464^{* * *}$ & $0.433^{* * *}$ \\
\hline S.e. & {$[0.017]$} & {$[0.021]$} & {$[0.026]$} & {$[0.070]$} & {$[0.067]$} & {$[0.091]$} & {$[0.027]$} & {$[0.031]$} & {$[0.038]$} \\
\hline Observations & 15,362 & 10,073 & 6,005 & 15,362 & 10,073 & 6,005 & 15,362 & 10,073 & 6,005 \\
\hline \multicolumn{10}{|c|}{ Import Starters vs Never } \\
\hline$\gamma^{O L S}$ & $0.254^{* * *}$ & $0.273^{* * *}$ & $0.282^{* * *}$ & $0.123^{* *}$ & $0.100^{* *}$ & 0.003 & $0.968^{* * *}$ & $1.035^{* * *}$ & $0.962^{* * *}$ \\
\hline S.e. & {$[0.017]$} & {$[0.021]$} & {$[0.027]$} & {$[0.061]$} & {$[0.049]$} & {$[0.045]$} & {$[0.027]$} & {$[0.031]$} & {$[0.041]$} \\
\hline Observations & 15,662 & 10,402 & 6,252 & 15,662 & 10,402 & 6,252 & 15,662 & 10,402 & 6,252 \\
\hline \multicolumn{10}{|c|}{ Two-way Starters vs Never } \\
\hline$\gamma^{O L S}$ & $0.336^{* * *}$ & $0.373^{* * *}$ & $0.419^{* * *}$ & $0.103^{*}$ & $0.234^{* *}$ & $0.300^{* *}$ & $0.928^{* * *}$ & $0.991^{* * *}$ & $1.081^{* * *}$ \\
\hline S.e. & {$[0.030]$} & {$[0.034]$} & {$[0.043]$} & {$[0.053]$} & {$[0.106]$} & {$[0.144]$} & {$[0.043]$} & {$[0.051]$} & {$[0.062]$} \\
\hline Observations & 14,595 & 9,521 & 5,648 & 14,595 & 9,521 & 5,648 & 14,595 & 9,521 & 5,648 \\
\hline \multicolumn{10}{|c|}{ Two-way Starters vs Export Starters } \\
\hline$\gamma^{O L S}$ & $0.257^{* * *}$ & $0.275^{* * *}$ & $0.317^{* * *}$ & -0.04 & 0.024 & 0.161 & $0.513^{* * *}$ & $0.538^{* * *}$ & $0.648^{* * *}$ \\
\hline S.e. & {$[0.033]$} & {$[0.038]$} & {$[0.049]$} & {$[0.084]$} & {$[0.127]$} & {$[0.162]$} & {$[0.048]$} & {$[0.058]$} & {$[0.070]$} \\
\hline Observations & 1,833 & 1,426 & 1,011 & 1,833 & 1,426 & 1,011 & 1,833 & 1,426 & 1,011 \\
\hline \multicolumn{10}{|c|}{ Two-way Starters vs Import Starters } \\
\hline$\gamma^{O L S}$ & $0.079^{* *}$ & $0.103^{* * *}$ & $0.137^{* * *}$ & -0.021 & 0.132 & $0.299^{* *}$ & -0.038 & -0.035 & 0.116 \\
\hline S.e. & {$[0.033]$} & {$[0.039]$} & {$[0.049]$} & {$[0.080]$} & {$[0.114]$} & {$[0.143]$} & {$[0.049]$} & {$[0.058]$} & {$[0.072]$} \\
\hline Observations & 2,133 & 1,755 & 1,258 & 2,133 & 1,755 & 1,258 & 2,133 & 1,755 & 1,258 \\
\hline \multicolumn{10}{|c|}{ Import Starters vs Export Starters } \\
\hline$\gamma^{O L S}$ & $0.177^{* * *}$ & $0.170^{* * *}$ & $0.180^{* * *}$ & -0.021 & -0.103 & -0.14 & $0.550^{* * *}$ & $0.576^{* * *}$ & $0.532^{* * *}$ \\
\hline S.e. & {$[0.023]$} & {$[0.028]$} & {$[0.035]$} & {$[0.091]$} & {$[0.080]$} & {$[0.094]$} & {$[0.036]$} & {$[0.041]$} & {$[0.052]$} \\
\hline Observations & 2,900 & 2,307 & 1,615 & 2,900 & 2,307 & 1,615 & 2,900 & 2,307 & 1,615 \\
\hline
\end{tabular}

Standard errors in brackets.

Robust standard errors from OLS, S.e., are displayed.

$\gamma^{O L S}$ refers to the unconditional effect retrieved from simple OLS regressions on the unmatched samples for each treatment pairs. Year dummies have been included in all regressions,

${ }_{* *}^{*}$ Significant at $10 \%$ level.

${ }^{* *}$ Significant at $5 \%$ level.

${ }^{* * *}$ Significant at $1 \%$ level. 
Table 10. Employment effects of firm trade: robustness checks

\begin{tabular}{|c|c|c|c|c|c|c|c|c|c|c|c|c|c|c|c|c|c|c|}
\hline & \multicolumn{6}{|c|}{ Alternative logit specification } & \multicolumn{6}{|c|}{$\underline{\text { Starter definition based on both } t-1 \text { and } t-2}$} & \multirow{2}{*}{\multicolumn{3}{|c|}{$\begin{array}{l}\text { Overall Imports } \\
\text { Employment } \\
\end{array}$}} & \multirow{2}{*}{\multicolumn{2}{|c|}{$\mathrm{R} \& \mathrm{D} /$ Non- $\mathrm{R} \& \mathrm{D}$}} & \multirow[b]{3}{*}{$\Delta R_{2}$} \\
\hline & \multicolumn{3}{|c|}{ Employment } & \multicolumn{3}{|c|}{ R\&D/Non-R\&D } & \multicolumn{3}{|c|}{ Employment } & \multicolumn{3}{|c|}{$\mathrm{R} \& \mathrm{D} /$ Non- $\mathrm{R} \& \mathrm{D}$} & & & & & & \\
\hline & $\Delta L_{0}$ & $\Delta L_{1}$ & $\Delta L_{2}$ & $\Delta R_{0}$ & $\Delta R_{1}$ & $\Delta R_{2}$ & $\Delta L_{0}$ & $\Delta L_{1}$ & $\Delta L_{2}$ & $\Delta R_{0}$ & $\Delta R_{1}$ & $\Delta R_{2}$ & $\Delta L_{0}$ & $\Delta L_{1}$ & $\Delta L_{2}$ & $\Delta R_{0}$ & $\Delta R_{1}$ & \\
\hline \multicolumn{19}{|c|}{ Export Starters vs Never } \\
\hline$\gamma^{D I D}$ & 0.074 & 0.100 & 0.083 & 0.134 & 0.194 & 0.272 & 0.075 & 0.132 & 0.16 & -0.121 & -0.216 & -0.193 & 0.071 & 0.128 & 0.062 & 0.044 & 0.359 & 0.413 \\
\hline A.s.e. ${ }^{\mathrm{a}}$ & {$[0.021]^{* * *}$} & {$[0.032]^{* * *}$} & {$[0.046]^{*}$} & {$[0.147]$} & {$[0.170]$} & {$[0.262]$} & {$[0.025]^{* * *}$} & {$[0.044]^{* * *}$} & {$[0.077]^{* *}$} & {$[0.084]$} & {$[0.154]$} & {$[0.223]$} & {$[0.021]^{* * *}$} & {$[0.033]^{* * *}$} & {$[0.047]$} & {$[0.156]$} & {$[0.169]^{* *}$} & {$[0.281]$} \\
\hline B.s.e. $^{\mathrm{b}}$ & {$[0.024]^{* * *}$} & {$[0.036]^{* * *}$} & {$[0.052]$} & {$[0.159]$} & [0.199] & {$[0.311]$} & {$[0.031]^{* * *}$} & {$[0.054]^{* * *}$} & {$[0.090]^{*}$} & {$[0.121]$} & {$[0.201]$} & {$[0.261]$} & {$[0.026]^{* * *}$} & {$[0.039]^{* * *}$} & {$[0.059]$} & {$[0.158]$} & {$[0.213]^{*}$} & {$[0.346]$} \\
\hline Starters & 1298 & 840 & 486 & 1298 & 840 & 486 & 611 & 345 & 182 & 611 & 345 & 182 & 1250 & 818 & 475 & 1250 & 818 & 475 \\
\hline Controls & 1089 & 713 & 415 & 1089 & 713 & 415 & 546 & 306 & 162 & 546 & 306 & 162 & 1099 & 732 & 432 & 1099 & 732 & 432 \\
\hline \multicolumn{19}{|c|}{ Import Starters vs Never } \\
\hline$\gamma^{D I D}$ & 0.066 & 0.064 & 0.102 & 0.119 & 0.041 & -0.048 & 0.067 & 0.116 & 0.153 & 0.241 & 0.120 & 0.485 & 0.078 & 0.093 & 0.113 & 0.049 & 0.064 & -0.139 \\
\hline A.s.e. & {$[0.018]^{* * *}$} & {$[0.027]^{* *}$} & {$[0.040]^{* *}$} & {$[0.108]$} & {$[0.115]$} & {$[0.143]$} & {$[0.020]^{* * *}$} & {$[0.034]^{* * *}$} & {$[0.069]^{* *}$} & {$[0.185]$} & {$[0.241]$} & {$[0.257]^{*}$} & {$[0.018]^{* * *}$} & {$[0.027]^{* * *}$} & {$[0.041]^{* * *}$} & {$[0.099]$} & {$[0.123]$} & {$[0.189]$} \\
\hline B.s.e. & {$[0.022]$} & {$[0.030]^{* *}$} & {$[0.049]^{* *}$} & {$[0.138]$} & {$[0.163]$} & {$[0.216]$} & {$[0.024]^{* * *}$} & {$[0.046]^{* * *}$} & {$[0.082]^{* *}$} & {$[0.196]$} & {$[0.238]$} & {$[0.373]$} & {$[0.021]^{* * *}$} & {$[0.029]^{* * *}$} & {$[0.045]^{* *}$} & {$[0.135]$} & {$[0.155]$} & {$[0.249]$} \\
\hline Starters & 1597 & 1156 & 679 & 1597 & 1156 & 679 & 704 & 470 & 224 & 704 & 470 & 224 & 1601 & 1125 & 642 & 1601 & 1125 & 642 \\
\hline Controls & 1219 & 882 & 536 & 1219 & 882 & 536 & 598 & 394 & 198 & 598 & 394 & 198 & 1229 & 856 & 503 & 1229 & 856 & 503 \\
\hline \multicolumn{19}{|c|}{ Two-way starters vs Never } \\
\hline$\gamma^{D I D}$ & 0.209 & 0.309 & 0.316 & -0.220 & 0.120 & 0.103 & 0.115 & 0.185 & 0.168 & 0.128 & -0.025 & 0.07 & 0.172 & 0.243 & 0.298 & -0.273 & 0.032 & 0.054 \\
\hline A.s.e. & {$[0.036]^{* * *}$} & {$[0.049]^{* * *}$} & {$[0.068]^{* * *}$} & {$[0.263]$} & {$[0.193]$} & {$[0.245]$} & {$[0.045]^{* * *}$} & {$[0.072]^{* * *}$} & {$[0.108]$} & {$[0.191]$} & {$[0.266]$} & {$[0.512]$} & {$[0.029]^{* * *}$} & {$[0.045]^{* * *}$} & {$[0.054]^{* * *}$} & {$[0.159]^{* * *}$} & {$[0.172]$} & {$[0.205]$} \\
\hline B.s.e. & {$[0.038]^{* * *}$} & {$[0.052]^{* * *}$} & {$[0.072]^{* * *}$} & {$[0.219]$} & {$[0.249]$} & {$[0.324]$} & {$[0.052]^{* *}$} & {$[0.083]^{* *}$} & {$[0.142]$} & {$[0.242]$} & {$[0.337]$} & {$[0.682]$} & {$[0.039]^{* * *}$} & {$[0.052]^{* * *}$} & {$[0.074]^{* * *}$} & {$[0.174]$} & {$[0.240]$} & {$[0.302]$} \\
\hline Starters & 533 & 384 & 241 & 533 & 384 & 241 & 195 & 122 & 74 & 195 & 122 & 74 & 547 & 394 & 248 & 547 & 394 & 248 \\
\hline Controls & 484 & 349 & 218 & 484 & 349 & 218 & 187 & 117 & 70 & 187 & 117 & 70 & 497 & 354 & 222 & 497 & 354 & 222 \\
\hline \multicolumn{19}{|c|}{ Two-way Starters vs Export Starters } \\
\hline$\gamma^{D I D}$ & 0.085 & 0.129 & 0.113 & -0.446 & -0.091 & -0.033 & 0.034 & 0.076 & 0.014 & -0.081 & -0.164 & 0.163 & 0.081 & 0.087 & 0.085 & 0.1 & 0.25 & 0.268 \\
\hline A.s.e. & {$[0.030]^{* * *}$} & {$[0.044]^{* * *}$} & {$[0.068]^{* * *}$} & {$[0.259]^{*}$} & {$[0.207]$} & {$[0.341]$} & {$[0.043]$} & {$[0.091]$} & {$[0.125]$} & {$[0.18]$} & {$[0.23]$} & {$[0.551]$} & {$[0.031]^{* * *}$} & {$[0.046]^{*}$} & {$[0.062]$} & {$[0.189]$} & {$[0.254]$} & {$[0.405]$} \\
\hline B.s.e. & {$[0.037]^{* *}$} & {$[0.048]^{* * *}$} & {$[0.080]$} & {$[0.365]$} & {$[0.420]$} & {$[0.598]$} & {$[0.047]$} & {$[0.081]$} & {$[0.152]$} & {$[0.212]$} & {$[0.354]$} & {$[0.669]$} & {$[0.038]$} & {$[0.052]^{*}$} & {$[0.077]$} & {$[0.348]$} & {$[0.410]$} & {$[0.610]$} \\
\hline Starters & 532 & 405 & 268 & 532 & 405 & 268 & 193 & 124 & 69 & 193 & 124 & 69 & 547 & 392 & 263 & 547 & 392 & 263 \\
\hline Controls & 398 & 302 & 197 & 398 & 302 & 197 & 153 & 97 & 55 & 153 & 97 & 55 & 390 & 286 & 195 & 390 & 286 & 195 \\
\hline \multicolumn{19}{|c|}{ Two-way Starters vs Import Starters } \\
\hline$\gamma^{D I D}$ & 0.093 & 0.139 & 0.180 & -0.090 & -0.029 & 0.116 & 0.053 & 0.04 & 0.055 & -0.536 & -0.265 & -0.358 & 0.081 & 0.111 & 0.121 & 0.010 & 0.175 & 0.31 \\
\hline A.s.e. & {$[0.031]^{* * *}$} & {$[0.042]^{* * *}$} & {$[0.060]^{* * *}$} & {$[0.134]$} & {$[0.169]$} & {$[0.220]$} & {$[0.038]$} & {$[0.068]$} & {$[0.124]$} & {$[0.511]$} & {$[0.21]$} & {$[0.568]$} & {$[0.031]^{* * *}$} & {$[0.045]^{* *}$} & {$[0.063]^{*}$} & {$[0.199]$} & {$[0.234]$} & {$[0.311]$} \\
\hline B.s.e. & {$[0.034]^{* * *}$} & {$[0.048]^{* * *}$} & {$[0.075]^{* *}$} & {$[0.288]$} & {$[0.309]$} & {$[0.419]$} & {$[0.042]$} & {$[0.080]$} & {$[0.162]$} & {$[0.459]$} & {$[0.589]$} & {$[0.897]$} & {$[0.032]^{* *}$} & {$[0.051]^{* *}$} & {$[0.066]^{*}$} & {$[0.250]$} & {$[0.260]$} & {$[0.363]$} \\
\hline Starters & 531 & 400 & 272 & 531 & 400 & 272 & 194 & 128 & 77 & 194 & 128 & 77 & 547 & 405 & 280 & 547 & 405 & 280 \\
\hline Controls & 425 & 321 & 219 & 425 & 321 & 219 & 154 & 106 & 64 & 154 & 106 & 64 & 433 & 328 & 232 & 433 & 328 & 232 \\
\hline \multicolumn{19}{|c|}{ Import Starters vs Export Starters } \\
\hline$\gamma^{D I D}$ & 0.004 & -0.021 & 0.066 & 0.302 & 0.548 & 0.942 & 0.014 & 0.037 & -0.007 & 0.189 & -0.231 & -0.193 & -0.006 & -0.051 & 0.016 & 0.178 & -0.230 & 0.337 \\
\hline A.s.e. & {$[0.020]$} & {$[0.031]$} & {$[0.049]$} & {$[0.247]$} & {$[0.293]^{*}$} & {$[0.323]^{* * *}$} & {$[0.029]$} & {$[0.047]$} & {$[0.089]$} & {$[0.188]$} & {$[0.257]$} & {$[0.442]$} & {$[0.023]$} & {$[0.033]$} & {$[0.050]$} & {$[0.158]$} & {$[0.232]$} & {$[0.243]$} \\
\hline B.s.e. & {$[0.023]$} & {$[0.037]$} & {$[0.060]$} & {$[0.282]$} & {$[0.353]$} & {$[0.428]^{* *}$} & {$[0.026]$} & {$[0.054]$} & {$[0.097]$} & {$[0.198]$} & {$[0.294]$} & {$[0.497]$} & {$[0.022]$} & {$[0.036]$} & {$[0.061]$} & {$[0.222]$} & {$[0.357]$} & {$[0.439]$} \\
\hline Starters & 1577 & 1127 & 608 & 1577 & 1127 & 608 & 686 & 449 & 209 & 686 & 449 & 209 & 1574 & 1096 & 597 & 1574 & 1096 & 597 \\
\hline Controls & 731 & 521 & 318 & 731 & 521 & 318 & 337 & 213 & 114 & 337 & 213 & 114 & 719 & 495 & 303 & 719 & 495 & 303 \\
\hline
\end{tabular}

Standard errors in brackets.
${ }^{a}$ Analytical standard errors.

b Bootstrapped standard errors.

${ }^{*}$ Significant at $10 \%$ level.

${ }^{* *}$ Significant at $5 \%$ level.

*** Significant at $1 \%$ level. 
Table 11. Employment effects of firm trade: robustness checks II

\begin{tabular}{|c|c|c|c|c|c|c|c|c|c|c|c|c|}
\hline & \multicolumn{6}{|c|}{ Matching year-by-year and industry-by-industry } & \multicolumn{6}{|c|}{ Treated firms continuously exposed to treatment } \\
\hline & \multicolumn{3}{|c|}{ Employment } & \multicolumn{3}{|c|}{ R\&D/Non-R\&D } & \multicolumn{3}{|c|}{ Employment } & \multicolumn{3}{|c|}{ R\&D/Non-R\&D } \\
\hline & $\Delta L_{0}$ & $\Delta L_{1}$ & $\Delta L_{2}$ & $\Delta R_{0}$ & $\Delta R_{1}$ & $\Delta R_{2}$ & $\Delta L_{0}$ & $\Delta L_{1}$ & $\Delta L_{2}$ & $\Delta R_{0}$ & $\Delta R_{1}$ & $\Delta R_{2}$ \\
\hline \multicolumn{13}{|c|}{ Export Starters vs Never } \\
\hline$\gamma^{D I D}$ & 0.072 & 0.134 & 0.065 & -0.133 & -0.056 & -0.240 & 0.057 & 0.109 & 0.066 & 0.142 & 0.116 & -0.024 \\
\hline A.s.e. ${ }^{\mathrm{a}}$ & {$[0.019]^{* * *}$} & {$[0.033]^{* * *}$} & {$[0.049]$} & {$[0.137]$} & {$[0.132]$} & {$[0.255]$} & {$[0.021]^{* * *}$} & {$[0.038]^{* * *}$} & {$[0.052]$} & {$[0.146]$} & {$[0.211]$} & {$[0.424]$} \\
\hline B.s.e. ${ }^{\mathrm{b}}$ & {$[0.025]^{* * *}$} & {$[0.038]^{* * *}$} & {$[0.064]$} & {$[0.165]$} & {$[0.231]$} & {$[0.388]$} & {$[0.024]^{* *}$} & {$[0.043]^{* *}$} & {$[0.075]$} & {$[0.159]$} & {$[0.233]$} & {$[0.418]$} \\
\hline Starters & 1248 & 745 & 384 & 1248 & 745 & 384 & 1299 & 667 & 318 & 1299 & 667 & 318 \\
\hline Controls & 1071 & 653 & 329 & 1071 & 653 & 329 & 1105 & 590 & 281 & 1105 & 590 & 281 \\
\hline \multicolumn{13}{|c|}{ Import Starters vs Never } \\
\hline$\gamma^{D I D}$ & 0.095 & 0.091 & 0.148 & -0.027 & 0.059 & -0.041 & 0.074 & 0.119 & 0.208 & 0.097 & -0.101 & -0.613 \\
\hline A.s.e. & {$[0.020]^{* * *}$} & {$[0.029]^{* * *}$} & {$[0.047]^{* * *}$} & {$[0.110]$} & {$[0.113]$} & {$[0.145]$} & {$[0.018]^{* * *}$} & {$[0.033]^{* * *}$} & {$[0.057]^{* * *}$} & {$[0.120]$} & {$[0.137]$} & {$[0.288]^{* *}$} \\
\hline B.s.e. & {$[0.022]^{* * *}$} & {$[0.034]^{* * *}$} & {$[0.049]^{* * *}$} & {$[0.139]$} & {$[0.143]$} & {$[0.228]$} & {$[0.020]^{* * *}$} & {$[0.037]^{* * *}$} & {$[0.065]^{* * *}$} & {$[0.141]$} & {$[0.185]$} & {$[0.351]^{*}$} \\
\hline Starters & 1395 & 894 & 467 & 1395 & 894 & 467 & 1596 & 779 & 301 & 1596 & 779 & 301 \\
\hline Controls & 1123 & 702 & 376 & 1123 & 702 & 376 & 1223 & 619 & 259 & 1223 & 619 & 259 \\
\hline \multicolumn{13}{|c|}{ Two-way Starters vs Never } \\
\hline$\gamma^{D I D}$ & 0.191 & 0.268 & 0.257 & -0.16 & 0.028 & 0.362 & 0.182 & 0.316 & 0.404 & 0.052 & -0.002 & -0.036 \\
\hline A.s.e. & {$[0.033]^{* * *}$} & {$[0.048]^{* * *}$} & {$[0.067]^{* * *}$} & {$[0.128]$} & {$[0.188]$} & {$[0.246]$} & {$[0.031]^{* * *}$} & {$[0.052]^{* * *}$} & {$[0.079]^{* * *}$} & {$[0.156]$} & {$[0.184]$} & {$[0.277]$} \\
\hline B.s.e. & {$[0.040]^{* * *}$} & {$[0.058]^{* * *}$} & {$[0.084]^{* * *}$} & {$[0.181]$} & {$[0.244]$} & {$[0.330]$} & {$[0.039]^{* * *}$} & {$[0.069]^{* * *}$} & {$[0.105]^{* * *}$} & {$[0.190]$} & {$[0.297]$} & {$[0.474]$} \\
\hline Starters & 499 & 340 & 217 & 499 & 340 & 217 & 533 & 285 & 136 & 533 & 285 & 136 \\
\hline Controls & 466 & 320 & 204 & 466 & 320 & 204 & 492 & 259 & 122 & 492 & 259 & 122 \\
\hline \multicolumn{13}{|c|}{ Two-way Starters vs Export Starters } \\
\hline$\gamma^{D I D}$ & 0.052 & 0.104 & 0.182 & 0.211 & 0.538 & 1.312 & 0.064 & 0.119 & 0.177 & -0.224 & 0.401 & 1.339 \\
\hline A.s.e. & {$[0.033]$} & {$[0.057]^{*}$} & {$[0.086]^{* *}$} & {$[0.227]$} & {$[0.457]$} & {$[0.572]^{* *}$} & {$[0.031]^{* *}$} & {$[0.052]^{* *}$} & {$[0.086]^{* *}$} & {$[0.337]$} & {$[0.506]$} & {$[0.967]$} \\
\hline B.s.e. & {$[0.043]$} & {$[0.065]$} & {$[0.094]^{*}$} & {$[0.321]$} & {$[0.438]$} & {$[0.608]^{* *}$} & {$[0.035]^{*}$} & {$[0.064]^{*}$} & {$[0.117]$} & {$[0.336]$} & {$[0.457]$} & {$[0.879]$} \\
\hline Starters & 423 & 236 & 155 & 423 & 236 & 155 & 533 & 261 & 124 & 533 & 261 & 124 \\
\hline Controls & 327 & 184 & 118 & 327 & 184 & 118 & 392 & 200 & 102 & 392 & 200 & 102 \\
\hline \multicolumn{13}{|c|}{ Two-way Starters vs Import Starters } \\
\hline$\gamma^{D I D}$ & 0.111 & 0.204 & 0.059 & -0.2 & -0.067 & 0.43 & 0.091 & 0.122 & 0.237 & -0.108 & -0.061 & 0.098 \\
\hline A.s.e. & {$[0.033]^{* * *}$} & {$[0.055]^{* * *}$} & {$[0.090]$} & {$[0.299]$} & {$[0.291]$} & {$[0.458]$} & {$[0.029]^{* * *}$} & {$[0.053]^{* *}$} & {$[0.080]^{* * *}$} & {$[0.170]$} & {$[0.218]$} & {$[0.357]$} \\
\hline B.s.e. & {$[0.041]^{* * *}$} & {$[0.072]^{* * *}$} & {$[0.110]$} & {$[0.328]$} & {$[0.397]$} & {$[0.567]$} & {$[0.034]^{* * *}$} & {$[0.062]^{* *}$} & {$[0.109]^{* *}$} & {$[0.262]$} & {$[0.348]$} & {$[0.589]$} \\
\hline Starters & 440 & 271 & 140 & 440 & 271 & 140 & 532 & 276 & 137 & 532 & 276 & 137 \\
\hline Controls & 357 & 231 & 125 & 357 & 231 & 125 & 416 & 221 & 112 & 416 & 221 & 112 \\
\hline \multicolumn{13}{|c|}{ Import Starters vs Export Starters } \\
\hline$\gamma^{D I D}$ & 0.056 & -0.038 & 0.023 & 0.171 & 0.079 & 0.211 & -0.001 & -0.081 & 0.025 & 0.111 & 0.098 & 0.435 \\
\hline A.s.e. & {$[0.026]^{* *}$} & {$[0.050]$} & {$[0.090]$} & {$[0.245]$} & {$[0.354]$} & {$[0.573]$} & {$[0.021]$} & {$[0.046]^{*}$} & {$[0.088]$} & {$[0.156]$} & {$[0.297]$} & {$[0.458]$} \\
\hline B.s.e. & {$[0.028]^{* *}$} & {$[0.051]$} & {$[0.101]$} & {$[0.255]$} & {$[0.350]$} & {$[0.584]$} & {$[0.023]$} & {$[0.044]^{*}$} & {$[0.102]$} & {$[0.228]$} & {$[0.293]$} & {$[0.821]$} \\
\hline Starters & 960 & 429 & 152 & 960 & 429 & 152 & 1564 & 581 & 165 & 1564 & 581 & 165 \\
\hline Controls & 554 & 230 & 88 & 554 & 230 & 88 & 722 & 314 & 117 & 722 & 314 & 117 \\
\hline
\end{tabular}

Standard errors in brackets.

In the year-by-year and industry-by-industry matching a caliper of 0.01 has been imposed, thus causing the exclusion of some treated firms in the ATT computation.

a Analytical standard errors.

${ }^{\mathrm{b}}$ Bootstrapped standard errors.

${ }^{*}$ Significant at $10 \%$ level.

${ }^{* *}$ Significant at $5 \%$ level.

${ }^{* * *}$ Significant at $1 \%$ level. 
Table 12. Employment effects of firm trade: control for time-varying covariates

\begin{tabular}{|c|c|c|c|c|c|c|c|c|c|c|c|c|}
\hline & \multicolumn{6}{|c|}{ All sample of treated firms } & \multicolumn{6}{|c|}{ Treated firms continuously exposed to treatment } \\
\hline & \multicolumn{2}{|c|}{ Employment } & \multicolumn{2}{|c|}{ R\&D/Non-R\&D } & \multicolumn{2}{|l|}{ Output } & \multicolumn{2}{|c|}{ Employment } & \multicolumn{2}{|c|}{ R\&D/Non-R\&D } & \multicolumn{2}{|l|}{ Output } \\
\hline & $\Delta L_{1}$ & $\Delta L_{2}$ & $\Delta R_{1}$ & $\Delta R_{2}$ & $\Delta Y_{1}$ & $\Delta Y_{2}$ & $\Delta L_{1}$ & $\Delta L_{2}$ & $\Delta R_{1}$ & $\Delta R_{2}$ & $\Delta Y_{1}$ & $\Delta Y_{2}$ \\
\hline \multicolumn{13}{|c|}{ Export Starters vs Never } \\
\hline$\gamma^{D I D}$ & 0.056 & -0.026 & 0.118 & 0.007 & 0.168 & 0.128 & 0.07 & 0.019 & 0.109 & -0.013 & 0.205 & 0.166 \\
\hline S.e..$^{\mathrm{a}}$ & {$[0.030]^{*}$} & {$[0.041]$} & {$[0.164]$} & {$[0.290]$} & {$[0.037]^{* * *}$} & {$[0.057]^{* *}$} & {$[0.034]^{* *}$} & {$[0.047]$} & {$[0.199]$} & {$[0.404]$} & {$[0.043]^{* * *}$} & {$[0.072]^{* *}$} \\
\hline B.s.e. ${ }^{\mathrm{b}}$ & {$[0.036]$} & {$[0.058]$} & {$[0.201]$} & {$[0.337]$} & {$[0.046]^{* * *}$} & {$[0.068]^{*}$} & {$[0.042]^{*}$} & {$[0.073]$} & {$[0.246]$} & {$[0.459]$} & {$[0.056]^{* * *}$} & {$[0.086]^{*}$} \\
\hline Starters & 861 & 485 & 861 & 485 & 861 & 485 & 669 & 312 & 669 & 312 & 669 & 312 \\
\hline Controls & 737 & 412 & 737 & 412 & 737 & 412 & 591 & 273 & 591 & 273 & 591 & 273 \\
\hline \multicolumn{13}{|c|}{ Import Starters vs Never } \\
\hline$\gamma^{D I D}$ & 0.100 & 0.100 & -0.093 & -0.577 & 0.279 & 0.283 & 0.100 & 0.155 & -0.092 & -0.586 & 0.345 & 0.435 \\
\hline S.e. & {$[0.023]^{* * *}$} & {$[0.033]^{* * *}$} & {$[0.104]$} & {$[0.179]^{* * *}$} & {$[0.030]^{* * *}$} & {$[0.045]^{* * *}$} & {$[0.029]^{* * *}$} & {$[0.053]^{* * *}$} & {$[0.122]$} & {$[0.267]^{* *}$} & {$[0.037]^{* * *}$} & {$[0.066]^{* * *}$} \\
\hline B.s.e. & {$[0.029]^{* * *}$} & {$[0.038]^{* * *}$} & {$[0.155]$} & {$[0.223]^{* * *}$} & {$[0.038]^{* * *}$} & {$[0.056]^{* * *}$} & {$[0.036]^{* * *}$} & {$[0.060]^{* *}$} & {$[0.182]$} & {$[0.341]^{*}$} & {$[0.047]^{* * *}$} & {$[0.085]^{* * *}$} \\
\hline Starters & 1144 & 652 & 1144 & 652 & 1144 & 652 & 781 & 293 & 781 & 293 & 781 & 293 \\
\hline Controls & 882 & 522 & 882 & 522 & 882 & 522 & 620 & 253 & 620 & 253 & 620 & 253 \\
\hline \multicolumn{13}{|c|}{ Two-way Starters vs Never } \\
\hline$\gamma^{D I D}$ & 0.224 & 0.179 & 0.086 & 0.216 & 0.544 & 0.545 & 0.275 & 0.303 & -0.024 & -0.029 & 0.557 & 0.74 \\
\hline S.e. & {$[0.043]^{* * *}$} & {$[0.051]^{* * *}$} & {$[0.203]$} & {$[0.257]$} & {$[0.054]^{* * *}$} & {$[0.068]^{* * *}$} & {$[0.051]^{* * *}$} & {$[0.065]^{* * *}$} & {$[0.190]$} & {$[0.335]$} & {$[0.063]^{* * *}$} & {$[0.091]^{* * *}$} \\
\hline B.s.e. & {$[0.055]^{* * *}$} & {$[0.079]^{* *}$} & {$[0.254]$} & {$[0.382]$} & {$[0.069]^{* * *}$} & {$[0.091]^{* * *}$} & {$[0.067]^{* * *}$} & {$[0.106]^{* * *}$} & {$[0.297]$} & {$[0.570]$} & {$[0.077]^{* * *}$} & {$[0.116]^{* * *}$} \\
\hline Starters & 386 & 240 & 386 & 240 & 386 & 240 & 285 & 132 & 285 & 132 & 285 & 132 \\
\hline Controls & 353 & 214 & 353 & 214 & 353 & 214 & 259 & 117 & 259 & 117 & 259 & 117 \\
\hline \multicolumn{13}{|c|}{ Two-way Starters vs Export Starters } \\
\hline$\gamma^{D I D}$ & 0.058 & -0.015 & 0.007 & 0.234 & 0.170 & 0.155 & 0.082 & 0.133 & 0.329 & 1.35 & 0.194 & 0.263 \\
\hline S.e. & {$[0.038]$} & {$[0.058]$} & {$[0.231]$} & {$[0.430]$} & {$[0.050]^{* * *}$} & {$[0.069]^{* *}$} & {$[0.047]^{*}$} & {$[0.081]$} & {$[0.311]$} & {$[0.701]^{*}$} & {$[0.060]^{* * *}$} & {$[0.095]^{* * *}$} \\
\hline B.s.e. & {$[0.053]$} & [0.085] & [0.356] & {$[0.575]$} & {$[0.068]^{* *}$} & {$[0.089]^{*}$} & {$[0.063]$} & [0.119] & {$[0.423]$} & [0.865] & {$[0.077]^{* *}$} & {$[0.126]^{* *}$} \\
\hline Starters & 393 & 263 & 393 & 263 & 393 & 263 & 261 & 120 & 261 & 120 & 261 & 120 \\
\hline Controls & 289 & 197 & 289 & 197 & 289 & 197 & 200 & 100 & 200 & 100 & 200 & 100 \\
\hline \multicolumn{13}{|c|}{ Two-way Starters vs Import Starters } \\
\hline$\gamma^{D I D}$ & 0.114 & 0.141 & 0.011 & 0.193 & 0.28 & 0.256 & 0.126 & 0.213 & -0.057 & 0.125 & 0.242 & 0.37 \\
\hline S.e. & {$[0.035]^{* * *}$} & {$[0.052]^{* * *}$} & {$[0.169]$} & {$[0.237]$} & {$[0.049]^{* * *}$} & {$[0.069]^{* * *}$} & {$[0.046]^{* * *}$} & {$[0.079]^{* * *}$} & {$[0.220]$} & {$[0.380]$} & {$[0.058]^{* * *}$} & {$[0.097]^{* * *}$} \\
\hline B.s.e. & {$[0.053]^{* *}$} & {$[0.077]^{*}$} & {$[0.283]$} & {$[0.394]$} & {$[0.066]^{* * *}$} & {$[0.093]^{* * *}$} & {$[0.063]^{* *}$} & {$[0.108]^{* *}$} & {$[0.345]$} & {$[0.604]$} & {$[0.078]^{* * *}$} & {$[0.128]^{* * *}$} \\
\hline Starters & 410 & 275 & 410 & 275 & 410 & 275 & 276 & 134 & 276 & 134 & 276 & 134 \\
\hline Controls & 322 & 220 & 322 & 220 & 322 & 220 & 221 & 108 & 221 & 108 & 221 & 108 \\
\hline \multicolumn{13}{|c|}{ Import Starters vs Export Starters } \\
\hline$\gamma^{D I D}$ & -0.056 & -0.005 & -0.364 & 0.383 & 0.043 & 0.075 & -0.083 & -0.019 & 0.148 & 0.581 & 0.018 & 0.179 \\
\hline S.e. & {$[0.021]^{* * *}$} & {$[0.035]$} & {$[0.181]^{* *}$} & {$[0.174]^{* *}$} & {$[0.028]$} & {$[0.045]^{*}$} & {$[0.032]^{* * *}$} & {$[0.072]$} & {$[0.163]$} & {$[0.370]$} & {$[0.039]$} & {$[0.080]^{* *}$} \\
\hline B.s.e. & {$[0.034]^{*}$} & {$[0.061]$} & {$[0.338]$} & {$[0.431]$} & {$[0.045]$} & {$[0.070]$} & {$[0.042]^{*}$} & {$[0.099]$} & {$[0.307]$} & {$[0.847]$} & {$[0.057]$} & {$[0.119]$} \\
\hline Starters & 1100 & 620 & 1100 & 620 & 1100 & 620 & 581 & 163 & 581 & 163 & 581 & 163 \\
\hline Controls & 511 & 315 & 511 & 315 & 511 & 315 & 314 & 117 & 314 & 117 & 314 & 117 \\
\hline
\end{tabular}

Standard errors in brackets.

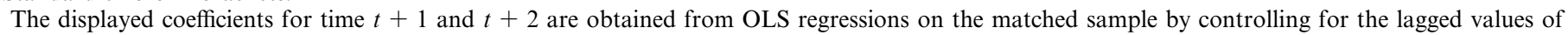

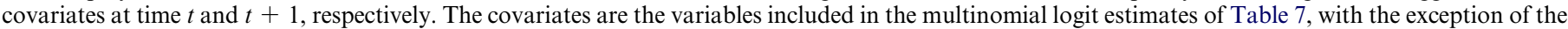
dependent variable in each regression.

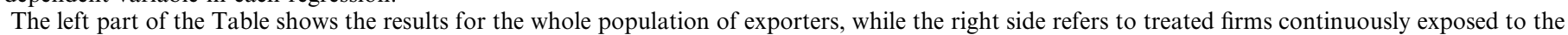
treatment after the entry.

The lower number of treated firms in some matching pairs is due to the lack of information about the lagged values of covariates.

${ }^{\text {a }}$ Standard errors from OLS

${ }^{\mathrm{b}}$ Bootstrapped standard errors.

* Significant at $10 \%$ level.

** Significant at 5\% level.

*** Significant at 1\% level. 


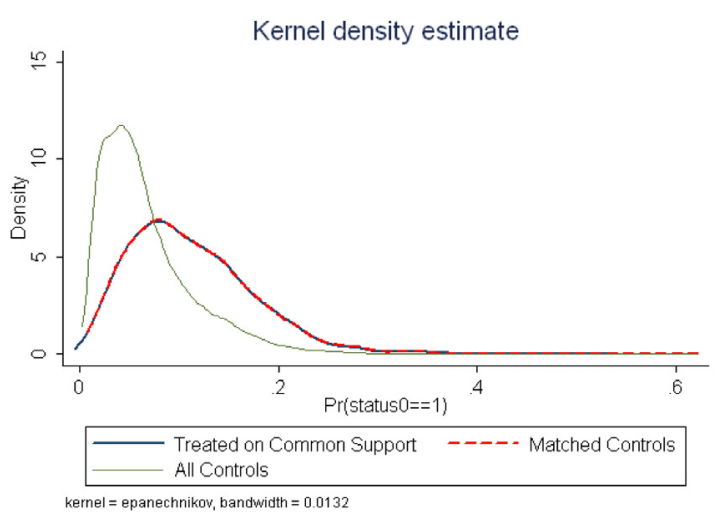

Export-Starters/Never

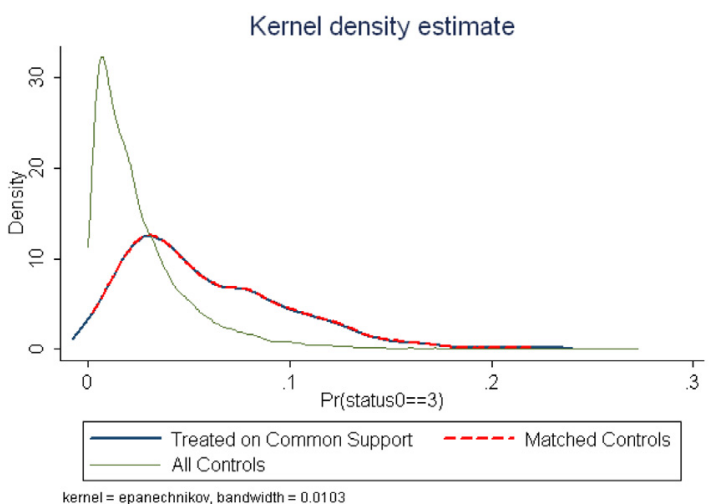

Two-way-Starters/Never

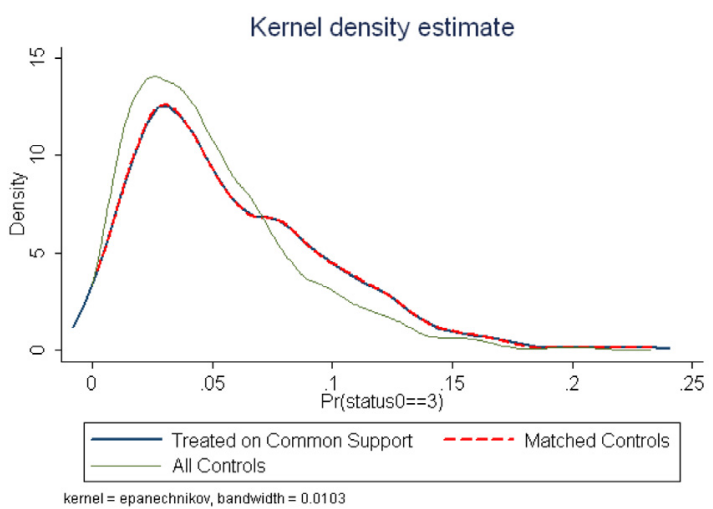

Two-way/Import-Starters

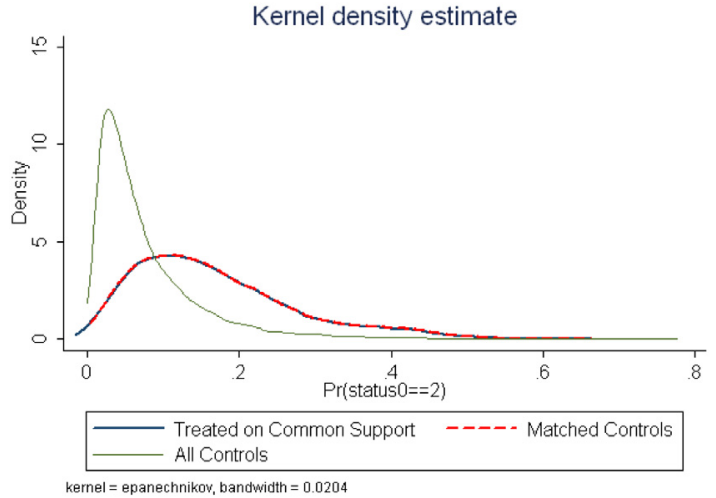

Import-Starters/Never

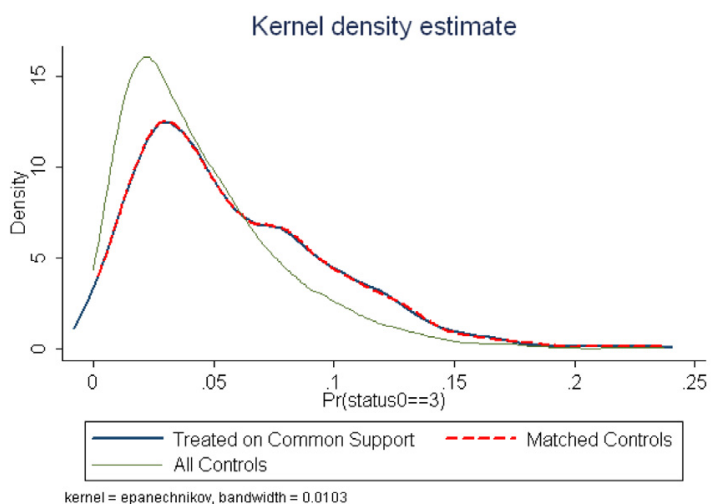

Two-way/Export-Starters

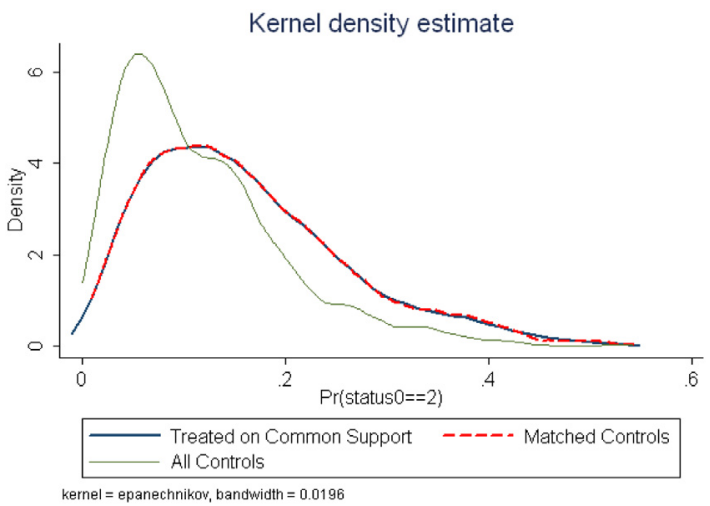

Import/Export-Starters

Figure A.0. Propensity score densities for the treated and matched and unmatched controls. Notes: Import Starter/Export Starter/Two-way Starter refers to the firm that importslexports/imports \& exports in $t$ and did not importlexport/import \& export in $t-1$. Never refers to firms which neither exports nor imports during the whole sample time span.

Available online at www.sciencedirect.com

\section{SciVerse ScienceDirect}

